\title{
The Unbalanced Growth Hypothesis and the Role of the State: the Case of China's State-owned Enterprises
}

Albert Hirschman's unbalanced growth hypothesis suggests that a developing economy invest in industries with high backward and forward linkages. A high degree of linkage means that the initial investment yields large profit opportunities in other industries. These profit opportunities are taken up by entrepreneurs, i.e., lead to investment in the backward and forward linked industries. The higher the degree of linkage of the industry in which the initial investment occurred, the faster the economy grows.

China is different from the typical developing economy. Due to a history of planned (balanced) development under state ownership, China at the beginning of the reform period had in place a broad industrial base. The issue of unbalanced growth in China then is one of strategic withdrawal of the state from low-linkage sectors and the continued presence of the state in high-linkage sectors. The evidence suggests that while the degree of linkage plays an important role in generating economic growth in China, current province-specific withdrawal strategies for the state sector may have no effect on economic growth.

JEL, all China:

R1 General Regional Economics

R11 Regional Economic Activity: Growth, Development and Changes

R12 Size and Spatial Distributions of Regional Economic Activity, Interregional Trade

R15 Econometric and Input-Output Models, Other Models

R58 Regional Government Analysis - Regional Development Policy

O1 Economic Development; O11 Macroeconomic Analyses of Economic Development

O2 Development Planning and Policy; O21 Planning Models, Planning Policy

O4 Economic Growth and Aggregate Productivity; O41 One, Two, and Multisector Growth Models

O53 Economwide Country Studies - Asia including Middle East

P21 Socialist Systems and Transitional Economies - Planning, Coordination, and Reform

P3 Socialist Institutions and Their Transitions

Keywords: linkage, state ownership, development strategy, industrial policy, economic growth, unbalanced growth hypothesis, input-output model, Albert Hirschman

\author{
Carsten A. Holz \\ Social Science Division \\ Hong Kong University of Science \& Technology \\ Clear Water Bay \\ Kowloon \\ Hong Kong \\ E-mail: socholz@ust.hk \\ Tel/fax: +852 2719-8557
}

8 June 2007

The work described in this paper was supported by a grant from the Research Grants Council of Hong Kong (Project HKUST6122/03H). 


\section{Introduction}

European reconstruction following World War II and Latin America's development efforts spurred economists to explore options for promoting economic development. Authors discussed balanced vs. unbalanced growth (Nurske and Hirschman), the need for a big push (Rosenstein-Rodan), growth with an unlimited supply of labor (Lewis), and stages of economic growth (Rostow). ${ }^{1}$ Hirschman (1958), writing from his experiences in Colombia, questions if a big push can overcome a low-level equilibrium trap of development and suggests instead an unbalanced growth strategy. He argues that by concentrating investment in key industries, governments could create supply bottlenecks for inputs into these key industries. These supply bottlenecks, or "backward linkages," lead to high prices for the demanded inputs and thereby to profit opportunities in upstream industries. The profit opportunities, together with the quasi-guaranteed demand for the inputs in the key industries, then induce private investment in the input industries. Similarly, low prices for the outputs of the key industries create profit opportunities downstream (forward linkages), and thereby induce private investment in downstream industries.

The unbalanced growth hypothesis was put to the test by Yotopoulos and Nugent (1973) in a study of six developed countries and five less developed countries. The authors, through quantitative analysis relating linkage coefficients to economic growth, reject the unbalanced growth hypothesis, but accept what they call a "balanced-growth" version of the linkage hypothesis in that conformance to a particular imbalance pattern defined by sectoral linkage coefficients leads to high growth. Their findings triggered extensive comments, with a rejoinder by Yotopoulos and Nugent (1976), but the linkage hypothesis was not further tested.

Yotopoulos and Nugent's analysis is problematic in three respects. Their quantitative analysis assumes that high linkage of a sector, in the unbalanced growth analysis, needs to come with rapid economic growth in that same sector of the economy. But a high-linkage sector has a larger multiplier impact on other sectors than the other sectors have on this highlinkage sector, which would suggest the possibility if not the likelihood of a below-average growth rate of the high-linkage sector. Second, Yotopoulos and Nugent base their measure of linkage on gross output value effects. Hirschman's argument, in contrast, focuses on profit opportunities created across other industries by investment in one particular high-linkage sector. Third, Yotopoulos and Nugent miss out on the potential role of the government in Hirschman's argument. Private entrepreneurs may have no interest in investing in high linkage industries if those are not profitable, or they may lack the funds needed to invest in capital-intensive high-linkage sectors. It is the government, with fiscal resources, that is in a position to bring the benefits of high-linkage industries' positive externalities to fruition.

The case of China is different from the typical developing economy in that, at the beginning of the economic reform period in 1978, China started out with a relatively balanced economic structure and with dominant state ownership across all sectors. For China in the reform period, the question is not so much one of which sector to develop first in the face of severe resource or other constraints, but one of how to allocate state resources. The Chinese government faces choices of which industries to continue to invest in, and from which industries to withdraw. The state has gradually withdrawn from some sectors of the economy, in part through privatization and ownership restructuring, but largely by opening

For an overview of the "developmental theories" of economic development see any economic development textbook, such as Cypher and Dietz (2004), or a selection of these authors' writings in Meier and Seers (1984). 
up access for non-state enterprises. ${ }^{2}$ Hirschman's theory of unbalanced growth, applied to China, suggests that at a time when private entrepreneurship is at an initial stage, the Chinese government can maximize economy-wide growth if it continues to invest in sectors with high linkage effects on profits in other sectors, and withdraws from sectors with low linkage effects. In other words, if the state retains a large share in sectors with high linkage effects, economic growth, following Hirschman's theory of unbalanced growth, should be rapid.

China is an ideal testing ground because at any point of time in the reform period we have 8 or 31 observations in form of regions or individual provinces, all subject to a similar institutional and cultural environment. Many of the complications of large-scale crosscountry studies are irrelevant. Furthermore, China's regions are of the size of the U.S., Japan or Europe, and China's provinces are of the size of individual European countries, i.e., of a size that would typically allow a complete industrial structure to emerge, making possible a meaningful comparison of local government policies in the context of the unbalanced growth hypothesis.

Direct government involvement in China's economy occurs largely through state-owned enterprises (SOEs). Over the past decade, SOEs have come under increasing criticism from economists. Thus, Nicholas Lardy $(1998$, p. 22) finds that "reforms to date have failed in large portions of the state-owned sector and that their ultimate success will depend on the willingness of the Chinese Communist Party to embrace privatization." Sachs (1998) argues: "Now China has reached the stage where it cannot delay the process [of SOE reform] any longer because there are too many problems. The losses are too great; the financial loss resulting from the money-losing state-sector is too serious." (p. 13) In the long run, "China must go along the way of privatization" (p. 19). A 1996 World Bank study finds that China ranks particularly low on enterprise and property rights reform and recommends the creation and allocation of property rights, which primarily translates into advice on privatization. Most recently, two World Bank economists (Yusuf, Nabeshima) and Perkins (2006) continue the argument for privatization, if not accelerated privatization, of China's SOEs: "The desirable next steps for China's long-running SOE reform ... would be the full privatization of industrial enterprises" (p. 42). Others confirm that privatization of SOEs tends to lead to better performance in the privatized SOEs (for example, Jefferson and $\mathrm{Su}, 2006$ ). ${ }^{3}$

But judging SOEs by their financial performance ignores the potentially significant positive externalities of SOEs, one of which is the linkage effect. Other positive externalities of SOEs have been noted before. Thus, Lin et al. $(1998,2003)$ point to the policy-determined burdens (distorted output prices, high capital intensity, and social burdens) that place SOEs at a disadvantage in comparison to non-state enterprises. Holz $(2002,2003)$ in quantitative assessments finds that if circulation taxes and capital intensity are controlled for, industrial

\footnotetext{
2 Furthermore, in the case of China the question is not one of a priori identifying high-linkage sectors and promoting investment in these sectors, but an ex-post analysis of if the government has in the reform period, when it gradually withdrew from some industries, continued to play an important role in high-linkage sectors, and if so, thereby promoted economic growth. The ex-post analysis cannot distinguish if the government consciously chose the sectors that it continues to invest in according to linkage effects or not, and, should linkage effects have influenced the government's choice, if the government was able to correctly identify highvs. low-linkage sectors. In a yet further twist, planners may actually have been able to overcome the shortcomings of the various linkage measures (identified below) and to derive more comprehensive measures of linkage effects than the available data and the theoretical concept of linkages measures allow us to do.

While much of the discussion on SOEs in recent years has focused on profitability, a literature on efficiency notes the inferiority of SOEs; for ex., Jefferson et al. (2000) also report a decline in total factor productivity of SOEs in the most recent period under examination, 1992-96.
} 
SOE profitability exceeds that of enterprises in other ownership forms. ${ }^{4}$ The potential linkage effect of SOEs has so far escaped attention. And yet, given China's consistently high growth rates over the past more than two decades, one may wonder if possibly strategic sectoral retention or dominance of state ownership does not play a significant role in this growth.

\section{The linkage effect on growth}

Rosenstein-Rodan (1984), one of the early development economists, argued for a concerted and substantial investment push by the government of a less developed country. Less developed countries are caught in a low-level equilibrium trap marked by (i) the presence of significant economies of scale which remain unexploited due to the lack of largescale investment, (ii) a lack of social overhead capital because private enterprises cannot internalize the positive externalities of social overhead capital, (iii) severe under-investment in other areas of large positive externalities, such as in education and on-the-job training, and (iv) disguised unemployment. Government investment is necessary to provide a "big push" of initial industrialization. Once the economy has taken off, private investment will crowd in and maintain the growth momentum.

Hirschman questions if a big push can overcome a low-level equilibrium trap of development because "its application requires huge amounts of precisely those abilities which we have identified as likely to be in very limited supply in underdeveloped countries [entrepreneurial and managerial ability]" (p. 53). Governments in developing countries also lack the funds necessary to finance simultaneous industrialization across all sectors of industry.

Hirschman's developing economy is marked by such characteristics as "hidden, scattered, or badly utilized" resources and abilities (p. 5), "latent abilities" (p. 7) instead of realized abilities, a "group-focus" with a generally accepted view that the benefits from development "must accrue equally to all" (p. 12), and inexperience in "agreement-reaching and cooperation-enlisting" (p. 19). Hirschman suggests the creation of "inducement mechanisms" to help overcome the various obstacles to development (pp. 24-8). Thus, by concentrating investment in key industries, governments could create supply bottlenecks for inputs into these key industries, i.e., make use of backward linkages. These supply bottlenecks lead to high prices for the demanded inputs and thereby profit opportunities. The profit opportunities, together with the quasi-guaranteed demand for these inputs in the key industries, then induce private investment in the input industries. Similarly, government-determined low prices for the outputs of the government-run industries create profit opportunities downstream, and thereby induce private investment in downstream industries (forward linkages). If the government focuses its investment on high-linkage sectors, the backward and forward linkages to other industrial sectors will create a wide range of investment opportunities for private enterprises.

Yotopoulos and Nugent (1973), in a study of six developed countries and five less developed countries, explore the applicability of the Hirschmanian linkage hypothesis through quantitative analysis. Between the two groups of countries, they find little difference

\footnotetext{
$4 \quad$ The various recent quantitative analyses of privatization appear to not control for such factors as the government-financed reductions in social burdens, the debt write-offs, and the restructuring that inevitably accompany privatization. I.e., the performance of newly privatized firms may improve due to reasons other than privatization.
} 
in the sectoral pattern of backward linkage coefficients (which they regard as a measure of total linkage). ${ }^{5}$ The linkage coefficients of the developed countries tend to be higher.

To examine the relationship between linkage and growth, they first calculate, for each of 36 (39) countries in 1950-60, what they term the "Hirschman-compliance index," namely the correlation coefficient between the sectoral total linkage indices and the sectoral growth rates across 18 (6) sectors; for each sector, the total linkage index is the sectoral average index of the six developed countries or the sectoral average index of the five less developed countries (applied to each of the 36/39 countries as appropriate). ${ }^{6}$ In a second step, the 36/39 countries' Hirschman-compliance index (one for each country) is correlated with the economy-wide growth rate. For a variety of scenarios (6 sectors or 13 manufacturing sectors; developed or less developed countries, all countries), this second-order correlation coefficient is insignificant. The authors therefore reject the Hirschman unbalanced growth hypothesis that countries which emphasized high-linkage sectors were able to achieve higher growth rates than countries that emphasized low-linkage sectors. However, the authors in further analysis find a "balanced-growth" version of the linkage hypothesis confirmed: ${ }^{7}$ conformance across sectors to a particular imbalance pattern defined by sectoral linkage indices leads to high growth.

Yotopoulos and Nugent's analysis appears problematic in several respects. First, it assumes that emphasis of high-linkage sectors implies high growth rates in these sectors in 1950-60. But it is unclear why this should be the case. A high-linkage sector, in order to exhaust all feasible backward and forward linkage effects of this sector in this period, need not grow faster than other sectors. The fact that a high-linkage sector has a larger multiplier impact on other sectors than the other sectors have on this high-linkage sector would even suggest the possibility if not the likelihood of a lower growth rate of this high-linkage sector. ${ }^{8}$

The association of high linkage with high growth carries over to Yotopoulos and Nugent's "imbalance index." Their "imbalance index" is based on the squared deviation of a sector's growth rate from the weighted economy-wide growth rate, where the weights are the sectoral total linkage indices entered multiplicatively (without further manipulation); the squared deviation is weighted by the sector's share in the country's GDP, before it is averaged across sectors. Taking the square root and dividing by the economy-wide growth rate yields the index of imbalance. This imbalance index, by design, assumes a low value (reflects a high degree of "balance") if a sector's growth rate is positively correlated with the sector's linkage index. But if high linkage of a sector were not necessarily to imply a high growth rate in this sector, i.e., if the correlation were random, then the imbalance index

\footnotetext{
Their sectoral "total linkage index" is the column sum of the Leontief inverse for that sector. This is the backward linkage coefficient introduced below in the second set of linkage coefficients.

6 The calculated Hirschman-compliance indices are not reported. The authors state: "The Hirschmancompliance indices that were computed varied significantly, depending on whether equation (4) [countryspecific correlation coefficient between sectoral total linkage coefficients and growth rates] or equation (4a) [also taking into account the relative importance of a sector in a country's economy, and differences in sectoral income elasticities of demand] was used" (p. 166).

In this case, the 18-sector scenario is reduced to a focus on 13 manufacturing industries (with no mentioning of the results in the 18 -sector case); the originally 36 countries in the 18 -sector scenario are now reduced to 34 (with no reason given).

8 While the linkage index measures the impact of one unit change in final demand of one particular sector on gross output value across the economy, the sectoral growth rate is presumably measured in terms of value added. (The authors do not report how they measure the sectoral growth rate.) It is, thus, also questionable to what extent the relationship between linkage index and economic growth rate measures something economically meaningful.
} 
becomes meaningless. Furthermore, the imbalance index assumes that sectoral growth rates exhibit a fixed linear relationship to the weighted economy-wide growth rate; i.e., perfect balance is achieved if sectoral growth rates deviate from the economy-wide growth rate by a multiple that exactly equals their linkage coefficient - not twice the linkage coefficient, nor one-third the linkage coefficient, and not differing in the proportion across sectors. This constitutes a rather arbitrary imposition.

Second, Yotopoulos and Nugent's sectoral total linkage coefficient measures the economy-wide change in gross output value given a unit-change in final demand for the products of the given sector. Hirschman (1958, p. 108), when briefly discussing operational measures of linkage, also includes this measure. However, in laying out his argument for unbalanced growth he explicitly focuses on profit opportunities: "our aim must be to keep alive [emphasis in original] rather than to eliminate the disequilibria of which profits and losses are symptoms in a competitive economy" (p. 66, and much of Chapter 4). I.e., the key to the linkage effect is the profit opportunities, which, in a second step, lead to output growth. The total linkage coefficient of Yotopoulos and Nugent provides no measure of the creation of profit opportunities. Hirschman himself, by not moving beyond the backward linkage coefficients in his operationalization of linkage measures, presumably has contributed to Yotopoulos and Nugent's questionable choice of linkage coefficient.

Third, Yotopoulos and Nugent do not take into account the government element of Hirschman's argument. Private entrepreneurs may have no interest in investing in high linkage industries if these are not profitable. Private entrepreneurs may not have the funds needed to invest in capital-intensive high-linkage sectors. A government with fiscal resources, on the other hand, is in a position to reap the benefits of high-linkage industries' positive externalities for the economy. ${ }^{9}$ Yotopoulos and Nugent miss out on the policy-oriented aspect of Hirschman's unbalanced growth theory. ${ }^{10}$

This 1973 paper by Yotopoulos and Nugent appears the only focused attempt in the literature to relate sectoral linkage coefficients to economy-wide growth. ${ }^{11}$ The concept of backward and forward linkages has, otherwise, found a number of other uses in the literature. $^{12}$

\footnotetext{
9 The importance of government pervades much of Hirschman's book, with the government either investing directly (much of Chapter 5) or implementing investment and other policies; in one location, in the core chapter on linkages (Chapter 6), Hirschman writes that "the rationale for interference with the market mechanism and consumers' preferences is particularly strong in slow-moving economies where industrial growth is incipient" (p. 116).

10 A discussion of Yotoupolos and Nugent's (1973) paper in a later issue of the Quarterly Journal of Economics by Laumas (1976), Boucher (1976), Riedel (1976), and Jones (1976) provides a number of arguments which, however, Yotoupolos and Nugent (1976) defend themselves against. Thus, sectors are weighted in their original analysis, imports are excluded in the calculation of their linkage coefficients, other linkage measures are highly correlated with theirs, and the level of aggregation was dictated by the data. 11 Nugent and Yotopoulos (1982) regress country growth rates on various measures of imbalance that include divergence from "normal" growth paths and sectoral linkage weights. No uniform conclusion emerges; the results indicate the need to differentiate by country groups and to control for country specifics. "Balanced growth," where sectors are linkage-weighted, could be slightly preferable. An earlier article by Yotopoulos and Lau (1970) examines the relationship of imbalance and growth without reference to linkages; it concludes in favor of balanced growth (and the authors defend their measure of imbalance in 1975).

12 Some examples of the wide range of studies using the linkage concept are the following. Roberts (1993) finds that the optimal sequence of privatization across 11 economic sectors of Poland is closely correlated with linkage effects, where privatization is modeled as a 10\% increase in efficiency. Thoburn (1973) examines the backward linkages from the demand for capital goods in Malaysia's tin, rubber and oil palm export industries on
} 
The analytical perspective in examining linkage effects in China is different from that laid out by Hirschman. At the beginning of the reform period, China was a planned economy in which resources were centrally or locally planned and distributed, with all benefits of development accruing first of all to the state. The typical obstacles to development of a developing economy were absent in China (which, on the other hand, faced the characteristic shortcomings of planned economies). China prior to the reform period did not need inducement mechanisms for development. The planners aimed for balanced growth, by design, and planning textbooks extolled balanced growth as one of the virtues of the socialist, planned economy. Thus, the planned economy was regarded as superior to the market economy because it led to "balanced and continuously rapid economic development of social production" and the "rational use" of resources, "thereby avoiding the enormous waste inherent in the anarchic production under capitalism.", 13

I $n$ the case of reform period China the question is not if there is a role for the government to step in and promote investment in high-linkage sectors. The question, rather, is if the government should continue to maintain a dominant share in some sectors, namely highlinkage sectors, while generally reducing the dominance of state ownership across the economy, especially by stepping out of certain other sectors, namely low-linkage sectors. At a time when private entrepreneurship is not yet well developed or the institutions to support large-scale private investment are not yet in place, government policies on the sectoral distribution of state ownership could be of crucial importance in determining economy-wide growth. An unbalanced growth strategy for state ownership in reform period China means that the government focuses its investment on those sectors which create high profit opportunities in other sectors.

A number of studies calculate (national) linkage effects for China. ${ }^{14}$ But linkage coefficients have not been related to either economic growth or state ownership. ${ }^{15}$ The questions here are to what extent linkage effects impact on economic growth in China, and to what extent the Chinese government considers linkage effects in decisions on the distribution of state ownership across sectors?

the development of a domestic light engineering industry. Sonis et al. (1996) trace the changes in gross outputs of European Union countries to changes in intra- and interregional backward linkage changes.

13 See the university textbook on the planned economy by Li Zhenzhong (1988), p. 17.

14 This includes Bhalla and Ma (1990) with a comparison of China's 1981 linkage coefficients to those in other countries and a focus on agricultural vs. rural non-farm vs. light industry vs. heavy industry linkages; Heimler (1991) with sectoral indices of vertical integration for 1981; Li Qiang and Xue Tiandong (1998) with sectoral linkage coefficients for 1981, 1983, 1987, 1990, 1992, and 1995 (using constant-price input-output tables); Liu Xiaoyu (2003) with sectoral linkage coefficients for 1997; Andreosso-O'Callaghan and Yue (2004) with an examination of the development of a range of sectoral linkage coefficients between 1987 and 1997; and SIC (2005) with linkage coefficients for 17 sectors in each of 8 regions in 1997.

15 Other input-output literature for China includes an examination of structural change over time (Coady and Li, 1993, for 1981, 1983 and 1987 using a proportional column filter; Li Qiang and Xue Tiandong, 1998, for 1981-83-87-90-92-95 also using a proportional column filter, and Andreosso-O'Callaghan and Yue, 2004, for 1987 and 1995 using a biproportional filter); and a decomposition of output growth into changes of final demand level, final demand structure, technical coefficients, and exports (Andreosso-O'Callaghan and Yue, 2002). Ichimura and Wang (eds., 2003) examine China's interregional dependence based on 7 regions and 9 sectors. Xu Xianchun and Liu Qiyun (2004) contain a large collection of short articles related to input-output analysis. Li Qiang (1992) is a textbook on input-output table techniques. Polenske and Chen (1991) present a historical overview over input-output tables in China as well as numerous applications that provide evidence of extensive applied input-output work in China. 


\section{Measuring "linkage"}

This section defines linkages, introduces the underlying analytical framework of inputoutput tables, and presents the linkage measures used here.

\section{Definition}

The concept of linkage evades a unique operational definition. Hirschman (1958, pp. 98ff.) distinguishes between the importance and the strength of the linkage effect, where importance could be captured by the net output of new industries that might be called forth, while strength would be reflected in the probability that these new industries will actually be created.

Hirschman offers two operational definitions of linkage. He first defines forward linkage of a particular industry as the proportion of total output of this industry that does not go to final demand but rather to other industries, and backward linkage, similarly, as the proportion of this industry's total output (input) that represents purchases from other industries. Second, a "more refined measure of backward linkage can be obtained by considering the inverse of the input-out matrix" (p. 108); he offers no counterpart for forward linkage.

Since Hirschman (1958), a large literature has developed on the various options for linkage measures and the optimal choice of linkage measures. Where Yotopoulos and Nugent focus on backward linkages, which they call "total" linkages, Cella (1984) proposes a total linkage coefficient based on the hypothetical extraction method: suppose a particular sector were absent from the economy, what would be the effect on the economy (or on the residual economy)? ${ }^{16}$ Further discussion about linkages concerns the measurement of both backward and forward linkages via the Leontief inverse of the matrix of input coefficients vs. the measurement of forward linkages based on a matrix of output coefficients (as introduced by Gosh 1958). ${ }^{17}$

\section{Input-output framework}

Linkage measures are derived from the input-output table as presented in Figure 1. Each row, or each column, can be read as one equation. Thus, the first row reads $\mathrm{X}_{11}+\mathrm{X}_{12}+\ldots+$ $X_{1 n}+Y_{1}=X_{1}$, i.e., the sum of all intermediate sales of the first sector (to all other sectors) plus final demand $\left(\mathrm{Y}_{1}\right)$ equals gross output value of the first sector $\left(\mathrm{X}_{1}\right)$. The typical question asked in input-output analysis is how gross output value across the economy changes in response to a particular sector's change in final demand? In order to solve the problem, a constant returns to scale technology is assumed: the proportions in which different inputs enter the production process of a particular sector are assumed constant over time; i.e., the

\footnotetext{
16 Cella also decomposes this total linkage coefficient into backward and forward linkages (with backward linkages, however, including some forward elements, and vice versa); Clements (1990) provides an adjustment to Cella's split of the total linkage measure into backward and forward linkage, which also implies a different normalization. Sonis et al. (1995) introduce the concept of pure linkages that further disentangles the backward and forward linkages. Cai and Leung (2005) interpret Sonis' pure linkages and suggest an alternative pure forward linkage measure for a symmetrical interpretation of pure backward and forward linkages.

17 For an overview of different linkage measures see Cai and Leung (2004) or Miller and Lahr (2001).
} 
input coefficients (also called "technical coefficients") $a_{i j}=X_{i j} / X_{j}$ are assumed constant. Replacing the $\mathrm{X}_{\mathrm{ij}}$ in the figure (or in the equation) by $\mathrm{a}_{\mathrm{ij}} * \mathrm{X}_{\mathrm{j}}$ yields, in matrix notation,

$$
\begin{aligned}
& \mathbf{A} \mathbf{x}+\mathbf{y}=\mathbf{x}, \text { or } \\
& \mathbf{x}=(\mathbf{I}-\mathbf{A})^{-1} \mathbf{y},
\end{aligned}
$$

where $\mathbf{x}$ is a column vector of sectoral gross output values $\left(X_{1}, \ldots, X_{n}\right), \mathbf{y}$ is a column vector of final demand $\left(\mathrm{Y}_{1}, \ldots, \mathrm{Y}_{\mathrm{n}}\right), \mathbf{A}$ is an $(n \times n)$ matrix of input coefficients $\mathrm{a}_{\mathrm{ij}}$, and $\mathbf{I}$ is the $(n \times n)$ identity matrix. The term $(\mathbf{I}-\mathbf{A})^{-1}$ is called the "Leontief inverse." For a given final demand vector, gross output value of all sectors follows. Similarly, for a given change in final demand, the change in gross output value of all sectors follows.

Alternatively, defining output coefficients (also called "allocation coefficients") as $\mathrm{b}_{\mathrm{ij}}=$ $X_{i j} / X_{i}$, i.e., as the proportion of sector $i$ 's sales that go to sector $j$, and writing each column of the input-output table as an equation, yields, in matrix notation,

$$
\begin{aligned}
& \mathbf{x}^{\prime} \mathbf{B}+\mathbf{w}^{\prime}=\mathbf{x}^{\prime}, \text { or } \\
& \mathbf{x}^{\prime}=\mathbf{w}^{\prime}(\mathbf{I}-\mathbf{B})^{-1},
\end{aligned}
$$

where $\mathbf{w}^{\prime}$ is a row vector of sectoral value added $\left(\mathrm{W}_{1} \mathrm{~W}_{2} \ldots \mathrm{W}_{\mathrm{n}}\right)$ reflecting, for each sector, the value of all primary inputs, and $\mathbf{B}$ is an $(n \times n)$ matrix of constant output coefficients $b_{i j}$. The term $(\mathbf{I}-\mathbf{B})^{-1}$ is called the "Ghosh inverse." For a given vector of primary inputs, gross output value of all sectors follows. In the interpretation of Dietzenbacher (1997), the Ghosh inverse captures the change in output values in response to changes in prices of primary inputs.

\section{Linkage measures}

Five sets of linkage indicators are summarized in Table 1. The first set of linkage indicators is Hirschman's first operational definition, with forward linkage (FL) of sector i defined as the proportion of total output of sector $i$ that does not go to final demand, and backward linkage (BL) as the proportion of purchases from other industries in sector i's total inputs (or, equivalently, output). This measure does not take into consideration feedback effects (i.e., indirect effects) between sectors.

The second set of linkage indicators consists of a BL measure in form of the column sum of the Leontief inverse, with elements $\alpha_{i j}$ of $(\mathbf{I}-\mathbf{A})^{-1}$, and a FL measure in form of the row sum of the Gosh inverse, with elements $\beta_{\mathrm{ij}}$ of $(\mathbf{I}-\mathbf{B})^{-1}$. This BL measure captures both the direct and indirect effect of a one-unit increase in final demand for the products of sector $\mathrm{j}$ on the output of all sectors; this includes the initial effect, the one-unit increase in output of sector $\mathrm{j}$ that comes from the one-unit increase in final demand for sector j's output. ${ }^{18}$ However, it

\footnotetext{
18 Diamond (1976) suggests two possible adjustments to the Leontief inverse, namely to subtract out the initial one-unit increase in the final demand for the particular sector under consideration, and to further omit the intraindustry effects in this sector. The first adjustment should not affect the ranking of sectors by linkage coefficient because each sector under consideration contains the initial one-unit increase in final demand.
} 
suffers from the inclusion of some forward linkage effects in the BL coefficient. ${ }^{19}$ Similarly, FL, which measures the impact of a one-unit change in the value of primary inputs on total output of each sector, suffers from the inclusion of some backward linkage effects in the FL coefficient. A "joint stability" problem applies in that if the A-matrix were constant over time, the B-matrix cannot be constant over time, and vice-versa. ${ }^{20}$

The third set of linkage indicators consists of Cai and Leung's (2004) Leontief SupplyDriven multiplier (LSD), which measures the total output change caused by a one-unit change to sector i's output and no change in other sectors' final demand, where equation i is extracted from the (Leontief) model; this is the backward linkage. (The mathematical setup described above is not elaborate enough to derive Cai and Leung's multipliers, or any of the following linkage measures; these all require a split matrix. For the straightforward but slightly more elaborate details see the cited authors.) The Gosh Supply-Driven multiplier (GSD) measures the total output change caused by a one-unit change to sector i's output (equivalently, input) and no change in other sectors' primary inputs, where equation $\mathrm{i}$ is extracted from the (Gosh) model. The LSD and GSD multipliers are derived using (i) the hypothetical extraction method (in which case the BL do not contain forward linkage elements, and similarly for FL), ${ }^{21}$ (ii) the Leontief inverse for BL and the Gosh inverse for FL (so that the BL and FL are defined symmetrically), and (iii) uniform output shocks (to avoid the implication of proportional shocks that, the larger the sector, the larger the linkage).

The fourth linkage indicator, an index of vertical integration (INT), follows from two manipulations of Cai and Leung's (2004) LSD, i.e., their total output change caused by a oneunit change to sector i's output. First, the initial one-unit change to sector i's output is not counted with the total output change. Second, the total output change is turned into value added (using sector-specific ratios of value added to gross output value), and divided by the original one-unit change in sector i's output that is now also turned into value added. I.e., this index of vertical integration measures the value added generated by sector $i$, outside sector $i$, per unit of value added in sector $i$. This is the index of vertical integration presented by Heimler (1991). A similar index, of horizontal integration, could be constructed using the Gosh inverse.

A fifth linkage indicator is the total linkage indicator (TL) in Miller and Lahr's (2001) case of total extraction of one sector. It is based on the question of by how much an economy's total output in all sectors, excluding sector i, would decrease if sector i were absent, i.e., if the $i^{\text {th }}$ row and column of the intermediate flow matrix as well as gross output value of sector $i$ were set equal to zero, and the needs for products of sector $i$ (in intermediate use of the non-i sectors or in final demand) were solely met through imports. In order to obtain a measure of the relative size of the loss, the loss of output in all sectors (excluding sector i) is related to the original output of sector $i$. The index measures the gross output value outside sector $i$ created by a one-unit increase in sector i gross output value. ${ }^{22}$

19 This is perhaps most easily visible when the Leontief inverse is rewritten as $(I-A)^{-1}=\left(I+A+A^{2}+A^{3}+\ldots\right)$. Writing out $\mathrm{A}^{2}, \mathrm{~A}^{3}$ etc. reveals the forward linkage input coefficients. BL and FL both share the intra-sectoral flows, i.e., the intra-sectoral flows are double-counted.

20 See Miller and Lahr (2001), p. 417, note 21, for details.

21 The intra-sectoral linkage $\left(a_{\mathrm{ii}}\right)$ is also not included.

22 A number of other total linkage indicators are possible and presented by Miller and Lahr (2001). Cella (1984) includes the output effect in the omitted sector in his total linkage effect; the part of his formula that covers the non-extracted sector is identical to the formula used here. In the context here, while government activity in one sector may trigger non-government activity in the same sector, the two cannot be distinguished, 
This fifth linkage indicator appears the most meaningful measure of linkage for examining the unbalanced growth hypothesis because it captures all linkage effects, backward and forward (and direct and indirect), without any double-counting. The distinction between backward and forward linkage may yield additional insights, but what matters primarily is the total effect, especially when backward and forward linkages cannot be meaningfully summed up.

Across geographic entities with identical sectoral classification, a comprehensive measure of linkage is available in form of an economy-wide (local) linkage coefficient, as the weighted sum of all linkage coefficients across sectors (BL, or FL, or INT, or TL), with as weights the sectoral output values or final demand values. This is a measure of the depth of industrial structure, called "coefficient of interdependence" by Jones (1976, p. 329). ${ }^{23}$ An economy with an, on average, higher coefficient of interdependence would appear to have more possibilities for backward and forward effects to spread. If growth initiatives were randomly distributed across sectors, then the economy in which such initiatives are amplified more than in another is likely to experience higher growth. ${ }^{24}$

Beyond measures of the degree of linkage, sectoral linkage indicators can also be aggregated into a measure of variation, such as the coefficient of variation. Underlying a measure of variation is the assumption that, given an equal depth of sectoral interdependence, linkage indicators of approximately equal size across sectors have a different impact on growth than linkage indicators of highly variable size across sectors.

Finally, all linkage measures can be translated into profit-linkage measures, i.e., into measures of how much profit is created economy-wide by one unit of additional final demand or gross output in a particular sector. The output linkage coefficient of a particular sector measures how a unit increase in final demand or gross output in one particular sector affects output across the sum of all sectors (possibly excepting the original change, or the sector in which the original change occurred). By, before summing the effects across all sectors, multiplying the output effect that a particular sector experiences by its ratio of operating surplus (the national income accounting measure of profit) to gross output value (or value added, depending on linkage measure), the in the literature typically used "output-"linkage turns into a profit-linkage measure. The sector-specific value of operating surplus is available in the input-output table; the operating surplus is one of the four components of value added (primary inputs). ${ }^{25}$

and it, therefore, seems more appropriate to examine the impact of the extracted sector on the non-extracted sectors.

${ }^{23}$ For the linkage coefficients calculated for the columns of the Leontief inverse or Gosh inverse, Jones (1976) shows that the sum of sectoral BLs weighted by the (sectoral) value of output equals the sum of sectoral FLs weighted by the (sectoral) value of output; i.e., the output-weighted sum of sectoral BLs or FLs equally yields the coefficient of interdependence.

24 In order to determine a relative degree of sectoral linkage, one option is to standardize by the average degree of linkage across the economy (linkage coefficient of a particular sector divided by average linkage coefficient across all sectors). Another option, if data on several geographic entities with identical sectoral classification are available, is to standardize by the average degree of linkage in the particular sector across geographic entities. Standardization is not needed below and therefore not further pursued.

25 For a discussion of the term "operating surplus" in the National Income and Product Accounts vs. the accounting term " profit," in the case of China's industry, see Holz (2003). Operating surplus in the agricultural sector in China is understated because farmers' net income is counted in full as labor remuneration (NBS, 1997, p. 26). 


\section{The use of quantitative measures to test Hirschman's unbalanced growth hypothesis}

Hirschman is well aware of the limitations of his linkage definitions in that he presents them as part of what he calls a "mental experiment" (pp. 104f.). Thus, it is assumed that the country's development started with the industry in question (rather than that the particular industry was set up last). For example, in the data on interdependence through purchases/ sales that he presents, he finds the largest value for backward linkage in grain mill products, but acknowledges that the cultivation of wheat and rice is not necessarily the result of the establishment of wheat and rice mills. In another example, he notes that the sectoral ranking of linkages does injustice to machinery and transport equipment, whose sales are largely to final demand. In terms of linkages, there is no essential difference between a stimulus towards establishing a machinery plant vs. an insecticide mixing plant. But while much of the output of the insecticide mixing plant is captured as linkage, that of the machinery plant is not. $^{26}$

Hirschman cautions against taking linkage rankings too seriously: "excessive reliance should obviously not be placed on these rankings, based as they are on a mental experiment subject to numerous qualifications" (p. 108). In the end, he appears somewhat more comfortable with backward linkages than with forward linkages. BL are likely to become effective as soon as domestic demand through new investment reaches a threshold. For FL, he finds it "absurd to set up any model that would presume to indicate which kind of metalfabricating industries would come into existence at what point of time in the wake of the establishment of a basic iron an steel industry" (p. 116).

Bulmer-Thomas (1982, section 12.5) cautions further. ${ }^{27}$ First, in a less developed country some sectors, perhaps especially those for which high linkages are expected, may not yet exist. One solution would be to use the linkage coefficients of other-typically developedcountries for which they are available. But he questions if the interdependence pattern found in less developed countries will eventually approximate that of more developed countries. Another solution would be to simply assume values for the missing input coefficients. The absence of precedents is less of a problem in the case of China in the reform period, because at the beginning of the reform period a basic industrial structure was already in place.

Second, an increase in gross output value is typically not a real world objective; an increase in income is. But this is not an argument for discarding linkage measures altogether. One way to address the issue is to use income multipliers to turn output linkage measures into income linkage measures, or employment multipliers to turn output linkage measures into employment measures. ${ }^{28}$

The question of real world objectives is also a question of what weights, if any, to apply in the derivation of sectoral linkage values. For example, in the case of the second backward

\footnotetext{
26 An intelligent planner may be able to take these shortcomings of linkage measures into account when ranking sectors by their linkage effects; i.e., the sectoral focus of SOEs in China in the reform period may be based on linkage effects but taking into account additional information. The following quantitative analysis does not attempt any adjustments to address the shortcomings of the linkage measures.

27 Other authors who raise questions about the meaning of linkage coefficients include Diamond (1976), McGilvray (1977), and Hewings (1982).

28 For income, this is meaningful only if imports are non-competitive. If all imports are competitive, a oneunit change in final demand necessarily implies a one-unit change in income (value added, value of primary inputs).
} 
linkage measure presented above, this means how to weight the Leontief inverse in the derivation of sectoral linkage coefficients. If one wants to avoid the assumption of a uniform one-unit final demand change across all sectors, one can apply the relative (sectoral) size of final demand. A further (or different) set of weights could be desirable depending on policy objectives. Thus, the Leontief inverse could be pre-multiplied by a diagonal policy matrix. However, policy objectives are likely to be multi-faceted and difficult to quantify. In the context here, the most relevant manipulation of the linkage measures is to turn them into profit-linkage coefficients as described above. It is the impact of whatever output change the government initiates on profit opportunities across the economy that triggers new investment and thereby economic growth.

Third, choosing sectors by linkage ranking ignores efficiency or comparative costs. A less developed country may be interested in increasing employment, but labor-intensive by definition means low-linkage in the input-output framework. ${ }^{29}$ Riedel (1976) reports on sectors in Taiwan with low domestic linkage coefficient which grew rapidly while intermediate inputs were imported. But this observation does not contradict the linkage hypothesis in that (i) the linkage coefficient of a particular sector need not have any implications for the growth rate of that particular sector (in the case here, a low sectoral BL comes with a high sectoral growth rate), and (ii) Riedel does not examine if import substitution occurs in the following years. This paper focuses on economy-wide growth; it also allows the linkage coefficients of one year to be related to economic growth several years later.

Fourth, ex ante linkage analysis comes with a severe flaw. Current linkage indices need not reflect future investment and growth opportunities that come into being after/ due to new government investment that potentially changes linkage values. ${ }^{30}$ Linkage indices of more developed countries could be applied, but this assumes that the country under examination will go through an identical development process. Ex post linkage analysis appears more meaningful, but carries no implications for the choice of development strategies and government investment policies that reach into the future; at best, it can be used to evaluate government policies. ${ }^{31}$ This paper provides an ex-post analysis in that it examines the government's allocation of SOEs in response to linkage values of different sectors and the ensuing effect on economy-wide growth. ${ }^{32}$

\footnotetext{
29 Switching to social accounting matrices would remedy the problem in that they take into account the use of the relatively large newly created income of laborers when investment occurs in high labor-intensity lowlinkage sectors. Lin (2003) promotes use of a "comparative advantage following" development strategy in China. 30 A counter-example is the potential for import substitution revealed by the difference between an intermediate input coefficient matrix that incorporates vs. excludes imports.

31 Bulmer-Thomas (1982, p. 196) sees a role for ex post linkage analysis to (i) check if government policy, at a given point of time, is consistent with the ranking of sectors, (ii) identify 'enclave' sectors (which could lead to promoting policies to integrate these into the national economy), (iii) track changes in the sectoral interdependence of a country over time, and (iv) make international comparisons at a given point in time. 32 Other limitations mentioned in the literature include the fact that the level of aggregation matters in the identification of key (high-linkage) sectors, and that inter-regional feedback mechanisms and induced effects via households are typically ignored. (See, for example, Hewings, 1982.) A further argument presented by BulmerThomas is that sectors with high backward linkages, by definition, depend heavily on intermediate goods, but these are often capital-intensive. The policy implications of favoring sectors with high backward linkages would be to support capital-intensive industries, but "this is not a position to which most LDCs [less developed countries] would want to be committed" (p. 195). This argument appears vague, and Bulmer-Thomas does not supported it with evidence. Hirschman (1984), p. 97, addresses it implicitly when he argues that "once the indirect employment effects (via backward and forward linkages) are taken into account, investment in large-
} 
Linkage measures come with a number of technical limitations. Thus, input (or output) coefficients are unlikely to be constant over time, whether due to technological change, economies of scale, the invention of new products, substitution due to relative price changes, changes in consumer preferences for the products within one sector or changes from domestically produced to imported inputs (and vice-versa). ${ }^{33}$ In the presence of transportation costs, the production structure could be influenced by the endowment with natural resources; a path dependence argument would run that if transportation costs were relatively high at some past point of time, the production structure established at that earlier point of time, corresponding to the local endowment with natural resources, is not immediately reversible.

The input-output model assumes final demand to be exogenous. But a change in final demand will trigger changes in primary inputs, which include household income, and a change in household income will have an impact on final household demand. In order to endogenize final household demand and primary inputs, a more elaborate social accounting matrix framework is necessary. But given the (public) non-availability for China of the necessary data, this is not an option. Compared to the direct and indirect effects captured in the input-output table framework, the induced effects via primary inputs are possibly minor. ${ }^{34}$

Given all these limitations, one may come to the conclusion that quantitative analysis of linkage effects cannot do justice to Hirschman's theory of unbalanced growth. Thus, McGilvray (1977), p. 56, writes: "It is regrettable that an original and valuable contribution to an understanding of economic development processes has been emasculated and oversimplified, a victim of the tendency to subordinate economic hypotheses to the restrictive requirements of elementary regression and correlation analysis. Thus measures of linkage have been reduced to the mechanical computation of index numbers."

The critique seems two-fold. A first aspect concerns the reduction of a book-length theory of unbalanced growth to an argument about linkages. The issue of linkages is one element of a multitude of insights into economic development. It is, thus, not possible to conclusively test the theory of unbalanced growth by testing just one element of it.

The term "unbalanced growth" itself is ambiguous. Does "unbalanced" mean that different sectors grow at different speed? Or does it mean that the level of development of one sector imposes a (slight / significant / severe?) constraint on the further development of another sector? Or should "unbalanced" be reduced to "differences in linkage values across sectors" (which would seem too narrow an interpretation of Hirschman's work)?

The second aspect of the critique concerns the measurement of linkages. There is no obvious choice of how to operationalize the concept of linkages; the measures based on input-output tables come with the limitations described above. Does that mean we should abandon all attempt at operationalization? If we did, would that not mean that Hirschman's work constitutes a non-falsifiable hypothesis? Hirschman appears to have outlined his theory

scale (capital-intensive) industry turns out to be just as employment-creating as investment in small-scale (laborintensive) industry for the industrially advanced countries of Latin America."

33 For a discussion see Miller and Blair (1985), pp. 267f.

34 The induced effects via primary inputs affect the ranking of sectors by the value of linkage coefficients if, for example, households' marginal expenditure pattern differs from their average expenditure pattern. Such differences are likely, but given that the induced effects are probably minor, they may not change the ranking of sectors. 
of unbalanced growth and the issue of linkages with policy implementation in mind; a nonfalsifiable hypothesis would scarcely be justified as an analytical tool informing development policy. Hirschman himself points the way by suggesting a (rather simplistic) linkage measure based on input-output tables - and then cautions against "excessive reliance" on rankings based on linkage values.

Others seem to have despaired of the intractability of "unbalanced growth" and, more generally, of the writings of the early development theorists. Thus, Krugman (1994) speaks of the "fall" of development economics because "high development theorists" (and that includes Hirschman) could not make the transition to "expressing their ideas in the kind of tightly specified models that were increasingly becoming the unique language of discourse of economic analysis" (p. 40) More recently, the idea of unbalanced growth, without necessarily being made explicit, seems to have reappeared in various forms, including a U-shaped pattern of sectoral diversification during the development process (Imbs and Wacziarg, 2003) and industrial policy recommendations (for example, Rodrik, 2006a,b). ${ }^{35}$

The approach taken in the following is to focus on two specific elements of the unbalanced growth theory and to test them using Chinese data: to what extent do linkage effects impact on economic growth, and to what extent does the Chinese government consider linkage effects in decisions on the distribution of state ownership across sectors? By focusing on these two specific elements and choosing specific methods of operationalization, the findings are necessarily limited. The findings are valid for the chosen operationalization of linkages, and are limited to the linkage aspects of the unbalanced growth theory. (This also obviates the need for a precise definition of "unbalanced growth.") It would seem preferable to think carefully about how to operationalize linkages and to cautiously interpret the external validity of the findings rather than to treat Hirschman's work as a non-falsifiable hypothesis.

\section{Evidence}

China before the reform period resembled an extreme form of the "big push" strategy of Rosenstein-Rodan. Virtually all investment in fixed assets, spread across all sectors of the economy, was undertaken by the state following a plan. In the planned economy, there was no scope for profit opportunities to induce private investment. In the reform period, however, state involvement has come to be more selective. If a high degree of linkage were to imply rapid economic growth - something to be examined - has the Chinese government in recent years then strategically concentrated state ownership in industries with high linkage effects (and thereby promoted economic growth)? The first step towards providing an answer is to calculate, for China, the various linkage measures introduced above.

\footnotetext{
35 Much of the industrial policy discussion concerns the interaction and cooperation between government and the private sector in establishing institutions that are conducive to further economic development. In contrast, analysis based on linkages tends to focus on production as input-output tables cover production. Hirschman (1958) cautions that investment in "social overhead capital" is in danger of being "overadvertised" (p. 86), that "a moderate shortage of SOC [social overhead capital] is not likely to do too much damage to a really dynamic developing area" (p. 95), and that "in a situation where SOC is not plentiful it may be more efficient to protect, subsidize, provide special finance for, or to undertake directly investment in DPA [directly productive activities] than to stimulate DPA indirectly through investment in SOC" (p. 89). Where Hirschman writes of "protection, subsidy, and special finance," Rodrik (2006b) writes "in this presentation of the facts, the government is only focused on providing complementary inputs to the market" (p. 25); Rodrik's details on the government's participation in the market appear slightly less interfering in productive activities than Hirschman may have had in mind.
} 


\section{Linkage values}

The calculation of linkage coefficients requires input-output tables. At the national level, input-output tables were compiled in 1981, 1983, 1985, 1987, 1990, 1992, 1995, 1997, 2000, and $2002 ;{ }^{36}$ not all of these are publicly available, and some of them draw heavily on the table of a few years earlier. The most independently compiled tables are those of 1981, 1987, 1992, 1997, and 2002. At the provincial level, input-output tables appear to be compiled equally regularly, and in great detail, but these tend to not be published. ${ }^{37}$ Only the inputoutput tables of a few provinces, for a few sporadic years, have been published, and many of those that have been published are reported with only a small number of sectors (at the extreme, just six sectors). A multi-regional input-output table for 1997 dividing China into eight regions with 17 sectors is available (SIC, 2005), as well as an inter-regional inputoutput table for 1987 with seven regions and nine sectors (Ichimura and Wang, 2003).

With the province as unit of analysis, provincial input-output tables would be ideal. But the scarcity of these tables rules out this possibility. This leaves a choice between national tables, with the national linkage coefficients applied equally to all provinces, and regional tables, with the regional linkage coefficients applied equally to all provinces in that region. In the following, the multi-regional input-output table for 1997, with eight regions and 17 sectors, is used. ${ }^{38}$ In contrast to the national input-output tables, the multi-regional one covers only one year, but then yields region-specific linkage coefficients. The 1987 inter-regional input-output table comes with too few sectors to be of use here. ${ }^{39}$

In the multi-regional 1997 input-output table, by construction, all inter-regional and all international trade flows are treated as internationally competitive and domestically noncompetitive. In detail, this means the following. If final demand for the goods/services of a particular sector increases - whether through an increase of final demand in this region, in other regions, or abroad - some of the new final demand translates into output growth in other regions through imports of intermediate inputs into this region from other regions. Similarly, if final demand in another region increases, this may result in an increase of intermediate inputs provided by this region to the other region. In the multi-regional 1997 input-output table, this region's input coefficients are net of the demand for intermediate inputs of this region by other regions, and net of the supply of intermediate inputs from this region to other regions; i.e., the regional input regional coefficients consider the impact of 'final demand for the products of this region' on 'production in this region' (only). By construction of the multi-regional input-output table, none of the additional final demand has any impact on international trade flows; all inter-regional (domestic) and all international

\footnotetext{
36 An input-output table was possibly also compiled for 1973. Naughton (2003) thinks that provincial inputoutput tables should exist, in accordance with the 5-year frequency, for 1982, 1987, 1992, 1997, and 2002. 37 Some of the (few) early provincial input-output tables that are available in the West are stamped "secret" (juemi).

38 The eight regions are Northeast (Heilongjiang, Jilin, Liaoning), Beijing-Tianjin, North (Hebei, Shandong), East (Jiangsu, Shanghai, Zhejiang), South (Fujian, Guangdong, Hainan), Central (Shanxi, Henan, Anhui, Hubei, Hunan, Jiangxi), Northwest (Inner Mongolia, Shaanxi, Ningxia, Gansu, Qinghai, Xinjian), and Southwest (Sichuan, Chongqing, Guangxi, Yunnan, Guizhou, Tibet). The 17 sectors are listed in Table 3.

39 The nine sectors in the 1987 inter-regional input-output table are agriculture, mining and processing, light industry, energy industry, heavy industry and chemical industry, construction, transportation \& post \& telecommunications, commerce and catering, and "non-material" sectors (Ichimura and Wang, 2003, p. 14).
} 
trade flows are internationally competitive in that the new final demand is met by domestic production.

Ideally, the classification into competitive and non-competitive would be made according to actual competitiveness rather than systematically assuming that, domestically, interregional substitution in response to the final demand change cannot occur, and, internationally, that final demand changes have no effect on international trade (beyond the initial effect if the final demand change was a change in international trade). The latter assumption could be relaxed, i.e., international trade flows could be made non-competitive, if one assumes each sector's imports to occur in some specific proportion across sectors (and non-import final demand) to which it is directed; but it is doubtful if such proportionality assumptions are plausible. ${ }^{40}$ Therefore, this paper proceeds with the data as they are. One piece of consolation is that the domestic trade flows are not particularly large and are similar in aggregate size across regions. International trade flows are small except in three regions. ${ }^{41}$

In the following, each region's input-output data are considered in isolation, which implies a particular view of policy decisions on final demand changes: final demand choices are regarded as a regional decision. A regional decision-maker is likely to be interested in the effect of its final demand decision on this region's production; this is what the available data measure. A national decision-maker could be interested in the effect of its decisions on national production, in which case the trade flows between regions need to be explicitly considered. The choice made here to consider each region's input-output data in isolation is due to the strong provincial focus of economic activities and planning in China (with several provinces then adding up to a region). Even a national planner may plan locally, or at least take local issues into consideration. While national planning would not seem out of the question, the local planning option appears more realistic. Again, because domestic trade flows are not particularly large, the necessary choice between local vs. national planning is unlikely to be important.

The 1997 multi-regional input-output table yields a large number of linkage coefficients: five sets with a total of eight linkage coefficients (as described above and summarized in Table 1), each either in form of the regular (output) linkage coefficient or of a profit-linkage coefficient, for 17 sectors in each of the eight regions. Two ways to summarize the linkage results are (i) to compare, for one specific region, the linkage patterns across sectors for two

\footnotetext{
40 For example, suppose the reported value of imports of sector $\mathrm{i}$ in the imports column consists of solely noncompetitive imports. The way to proceed is to change the value of imports of sector $\mathrm{i}$ in the imports column from its negative value to zero and to reduce the sales from sector i to all intermediate purchasers and to all nonimport final demand by, in the aggregate, the same absolute value of imports; lacking additional information, the reduction could be distributed across columns of intermediate purchases and non-import final demand in proportion to the original total flows. The (column-sum) gross output value of sector i remains unchanged. All reductions also enter a new imports row with positive sign. These sets of adjustments are done for each sector in turn, so that the import column turns zero throughout. With the new row of imports offsetting the adjustments made to intermediate flows and non-import final demand, the row-sum gross output value of all sectors also remains unchanged.

41 Across the eight regions in 1997, for intermediate use between 8-13\% of GOV was domestically imported, while between $6-14 \%$ of final demand was. (These numbers, $8 \%$ etc., reflect an individual region's aggregate across sectors; the percentages differ further for each sector in a region.) On the domestic export side, between $8-21 \%$ of domestic gross output value of a region's intermediate sales went to other regions, and between 3-11 $\%$ of final demand. (Again, $8 \%$ etc. reflect a region's aggregate value.) International exports accounted for 4$13 \%$ of final demand (with imports not yet netted out of final demand, and final demand not yet corrected for errors and omissions), except in the three regions South (41\%), East (26\%), and Beijing-Tianjin (25\%).
} 
different measures of linkage at a time, and (ii) to compare the linkage values and patterns across sectors and across regions for one specific linkage measure.

The correlations between different linkage measures (across sectors within one region) are rather similar for the different regions. The case of Beijing-Tianjin serves as illustration (Table 2). For the output-linkage indicators, with a few exceptions, BL and FL coefficients are negatively correlated across sectors (using one of the four BL indicators at a time, where the index of vertical integration is a BL measure, combined with one of the three FL indicators). This implies that sectors with a high degree of BL typically have a low degree of FL. This pattern holds even for the case where the BL and FL indicators are from different sets of indicators. The different BL measures, furthermore, tend to be positively correlated, as do the different FL measures. In the case of the profit-linkage coefficients, no such patterns are apparent.

For the sake of parsimony, in the remaining calculations in this paper a choice among the different indicators needs to be made. In the case of profit-linkage, such a choice is not trivial because the different linkage indicators clearly measure linkages differently. Because what is of interest here is not the distinction between backward and forward linkages but the level of all linkages, the solution adopted here is to focus on the total linkage indicator (TL), which captures backward and forward linkages together. ${ }^{42}$

Table 3 and Table 4 focus on the TL in order to further examine linkage patterns across sectors and regions, Table 3 for the total output-linkage coefficient, from now on labeled "TOL" (i.e., the TL of Table 1), and Table 4 for the total profit-linkage coefficient "TPL" (i.e., the TL of Table 1 turned into a profit-linkage indicator). TOL coefficients vary substantially across sectors (Table 3), such as, for example, from 0.417 (mining) to 1.517 (construction) in the Northeast region; the TOL coefficient for mining implies that a oneyuan change in output of the sector mining comes with a 0.417 -yuan change in output in all other sectors of the economy. The coefficient of variation-of TOL coefficients across sectors in one region-ranges from 0.304 in the Northeast to 0.506 in the Central region. Weighting sectors (within one region) by their share in value added (in this region) leads to very similar results. The substantial variation of TOL coefficients across sectors within one region does not mean that different regions differ: across regions, the pattern of TOL values is rather similar. Correlation coefficients across sectors between any two regions are positive and significant at the $0.1 \%$ level ( $1 \%$ level in one case).

In the case of the total profit-linkage coefficients (Table 4), a one-yuan output change in a particular sector creates changes in operating surplus in the other sectors that are, on average across regions, around 0.04 yuan. This value obviously has to be much lower than the output creation value in the case of the TOL coefficients because operating surplus is just one of four component of value added, which in turn together with intermediate inputs adds up to gross output value. Weighting sectoral TPL coefficients by value added or operating surplus makes little difference to the average sectoral TPL of a region, and the values of the coefficient of variation in the case of the TPL coefficients (Table 4) are similar to those in the case of the TOL coefficients (Table 3).

\footnotetext{
42 As separate measures of BL and FL, the LSD and GSD appear most clearly defined, while the index of vertical integration (INT), as a variation of $\mathrm{BL}$, is of interest due to its focus on value added generated outside the manipulated sector.
} 
For the TPL, the Central region is a special case: output expansion in any one sector in the Central region has negative profit effects for the aggregate of all other sectors in the Central region. This does not seem plausible and raises questions about the data quality in the case of the Central region. In quantitative data analysis below that involves TPL, the Central region is controlled for. ${ }^{43}$

The pattern of linkage across sectors in the case of the TPL coefficients is no longer uniformly similar between any two regions. In half of all combinations of provinces, the correlation coefficient is positive and significant; in all seven combinations that involve the Central region it is negative (and significant in six), and in the remaining seven combinations it is positive and insignificant. In other words, there is much more variation in TPL coefficients across sectors between any two regions than is the case for TOL. Within a region, the variation is similar for the TOL coefficients and the TPL coefficients.

Regressing the region-and sector-specific TOL coefficients on region and sector dummies shows most sectors to be significantly different from each other, while all regions except the Northeast and the Southeast are similar to each other (data not reported in any table). In the case of the TPL cofficients, regions are also similar, except the Central region and the Southwest, while the typical sector differs from approximately half of the other sectors.

These results suggest, first, that linkage values differ systematically across sectors, a prerequisite for this study. Second, distinction of sectoral linkage values by region is suggested at least in the case of the TPL measure; below, region-specific (sectoral) linkage values are applied to all provinces within a region.

\section{Linkage and ownership}

Ownership data, needed to examine if state ownership is concentrated in high-linkage sectors, are available primarily for industry. The industry classification scheme underlying the 1997 multi-regional input-output table ("GB1994") has been in use since 1993, but the value added data of 1993, the first year that the System National Accounts with the variable value added was adopted, appear of dubious quality. ${ }^{44}$ Therefore it seems preferable to start the analysis with the year 1994. The classification system changed again in 2003 (to the "GB2002"), but the changes appear sufficiently minor to be ignored in the aggregation of industrial sectors needed to match the regional input-output table. The 40 industrial sectors of the GB1994 can be seamlessly aggregated into the 13 industrial sectors used in the 1997 multi-regional input-output table (following some explanations in the source, SIC, 2005), and the 39 industrial sectors of the GB2002 can be matched well. ${ }^{45}$

The available data by industrial sector do not cover all industrial production units. Except in the industrial or economic census years $(1995,2004)$, they only cover the directly reporting industrial enterprises (those that report regularly and directly to China's statistical authority). In the census years they cover a slightly larger aggregate, but still not all industrial production units. A comparison of the sectoral data on the directly reporting industrial enterprises with

\footnotetext{
43 In the input-output table, all sectors in the Central region except (13) other manufacturing, (14) utilities, and (17) other services have negative operating surplus. The fact that three out of the 17 sectors have positive operating surplus makes the conclusion of a systematic mistake in the data difficult.

44 See Holz (2003), p. 23.

45 The individual industrial sectors are listed and matched in Appendix 1.
} 
the census data (covering a slightly larger but still incomplete aggregate) shows that the production units not covered in the data on directly reporting industrial enterprises are concentrated in sectors which, in the data on directly reporting industrial enterprises, come with a low degree of state ownership. ${ }^{46}$ In other words, if in a particular industrial sector the share of state-owned enterprises in the output of all directly reporting industrial enterprises is low, then it is likely to be even (substantially) lower in the (unknown) output of all production units in this industrial sector. On the other hand, if, in a particular industrial sector the share of state-owned enterprises in the output of all directly reporting industrial enterprises is high, then it is likely to be the same or only minimally lower in the (unknown) output of all production units in this industrial sector.

Thus, in terms of the share of state ownership in sectoral value added, the true share is likely to follow a more pronounced pattern than the one found in the available data on the directly reporting industrial enterprises. When indicators that are introduced below use sectoral value added weights, these are by necessity based on value added of the state-owned enterprises or of all directly reporting industrial enterprises.

The data on directly reporting industrial enterprises come with three complications that cannot be resolved. First, data on the directly reporting industrial enterprises typically include a sub-category state-owned enterprises, but the definition of this sub-category changed in 1998. Through 1997, "SOEs" comprise the traditional state-owned enterprises, state-owned joint operation enterprises (a very small category covering co-operations of two or more state-owned enterprises), and solely state-invested limited liability companies, together here labeled "SOEs." Since 1998, what is typically published is data on "state-owned and statecontrolled enterprises" (SOSCEs). These comprise the "SOEs" as previously and, furthermore, all other shareholding companies (i.e., all other limited liability companies, plus all stock companies) in which the state has an absolute or relative controlling share. ${ }^{47}$ The Company Law was passed in 1992 and enterprises only gradually switched to the company system, which puts some limitation on the statistical break between the SOE and SOSCE series in 1997-98. ${ }^{48}$ Provincial statistical yearbooks, the only source of provincial industrial data by sector, switched to the new classification only gradually, but by 2000 most provinces had adopted the new category SOSCEs. The notation "SOEs" in the following is taken to cover both concepts, SOEs and SOSCEs, with the exact coverage determined by the year.

Second, the definition of the directly reporting industrial enterprises also changed in 1998. Up through 1997, the directly reporting industrial enterprises comprise all enterprises with independent accounting system at township level and above (which include all SOEs), and since 1998 all state-owned and state-controlled enterprises plus all non-state enterprises with independent accounting system and annual sales revenue in excess of 5m yuan RMB. The statistical break in the overall coverage of the directly reporting industrial enterprises is on the order of a few percentage points: in 1997, the directly reporting industrial enterprises

\footnotetext{
46 For details, see Holz (2006b).

47 For details see Holz (2003), p. 18, with a correction posted at http://ihome.ust.hk/ socholz/SOEdefinition.htm (that also includes a definition of "absolute" and "relative" control). Details on the restructuring of the complete ownership classification are in Holz and Lin (2001); the "state" category (described in that source), as newly defined by China's National Bureau of Statistics in 1998, seems to not have come into widespread use.

48 The SOE share in the value added of the directly reporting industrial enterprises in 1997 was $46.3 \%$, and the SOSCE share in 1998 57.0\%. SOEs had value added of 919.293b yuan RMB in 1997, and SOSCEs of 1107.690 b yuan RMB in 1998, with an approximately 5\% deflation rate in industry. (Statistical Yearbook 1998, p. $444 ; 1999$, pp. $55,57,432)$
} 
accounted for $62.5 \%$ of industrial value added, and in 1998 (following the new definition), for $58.1 \%{ }^{49}$

Third, the economic census of 2004 unearthed a number of enterprises with annual sales revenue in excess of $5 \mathrm{~m}$ yuan RMB that had previously managed to escape the reporting requirement. Thus, the 2004 gross output value of the directly reporting industrial enterprises was revised upward from 18.7 trillion yuan RMB to 22.2 trillion yuan RMB, and the share of the directly reporting industrial enterprises in industrial value added went from $87.2 \%$ in prerevision 2004 to $93.9 \%$ in post-revision $2005 .^{50}$

Because of the data complications surrounding the economic census, the analysis in the following ends with the year 2003. With a starting year of 1994 and linkage coefficients for 1997, this suggests a focus on four individual years / three periods: 1994, 1997, 2000, and 2003. One period, then, precedes the measurement of the linkage values, while two periods follow.

Table 5 presents the correlation coefficients between linkage values and state shares across the 13 industrial sectors. If China's government were to focus state investment in sectors with high linkage effects, the share of state ownership in the output of a particular sector should be positively correlated with the sectoral linkage coefficient. As Table 5 shows for the TOL and TPL, province by province, and region by region, for the years 1994, 1997, 2000 , and 2003, this is not the case. Only a very few of the correlation coefficients are significant, and all that are significant are negative (as most non-significant ones are), suggesting that the state in these provinces (regions) in these years accounts for a large share of output in sectors with low linkage coefficients. Apart from the very few instances of significant correlations, there seems no significant relationship between the state share in the output of a particular sector and the linkage coefficient of that sector, but an underlying tendency towards a negative (albeit often not significant) relationship. ${ }^{51}$

But perhaps the Chinese government was only aware of the BL (that are more likely to take effect than the FL, as Hirschman argued)? Repeating Table 5 for the LSD and INT linkage indicators (not reported in any table) yields near-identical results as in the case of the total linkage coefficient.

The results are very similar if TOL and TPL are correlated across sectors with the ratio of SOE value added in a particular sector to all SOE value added, i.e., if the sectoral SOE share is not measured as the share in the output of all directly reporting industrial enterprises of the same sector, but as the share of output of SOEs across all sectors. The correlation coefficient tends to be negative but not significant except in a few instances.

This first finding is unexpected in the context of the unbalanced growth hypothesis. If the state wanted to promote economic development, one would expect the state to retain a large

\footnotetext{
$49 \quad$ Statistical Yearbook 1998, pp. 55, 444; 1999, pp. 55, 433.

50 For gross output values see Statistical Yearbook 2005, p. 488; 2006, p. 508. (Post-economic census value added data for the directly reporting industrial enterprises in 2004 are not available.) For the shares in value added see Statistical Yearbook 2005, pp. 51, 489; 2006, pp. 57, 511. Given that a revised 2004 value of the industrial value added of the directly reporting industrial enterprises is not available, the comparison of the two shares relies on pre-economic census 2004 values vs. post-economic census 2005 values.

51 The results are very similar if, for each province at a time, changes in the sectoral shares of SOEs over any one of the three periods (in relative or absolute terms) are correlated with the sectoral linkage coefficients.
} 
ownership share in high linkage sectors. But perhaps in the case of China, high linkage effects do not come with rapid economic growth and the state, if it is interested in economic growth, then would fare well to stay away from high linkage sectors. Or is the link between ownership and degree of linkage of a sector more subtle in that other factors need to be controlled for?

\section{Linkage, state ownership, and real GDP growth}

The final analysis examines the impact of linkage and ownership factors on provincial real GDP growth. Table 6 reports the results of regressing provincial real GDP growth on (provincial) economy-wide total linkage coefficients, ownership variables, and interactions of total profit linkage and ownership variables. Linkage coefficients cover the 13 industrial out of the total of 17 sectors, because only on these 13 industrial sectors is sufficient ownership information available.

The first regression in Table 6 examines the impact of provincial industry TOL (regional sectoral TOL of the 13 industrial sectors weighted by provincial sectoral value added of the directly reporting industrial enterprises at the beginning of the period) and the (correspondingly weighted) coefficient of variation of TOL on provincial economic growth; dummies for the first and the third time period are also included. Neither TOL nor its coefficient of variation are significant. Splitting TOL into the three periods makes no difference (not reported in the table). ${ }^{52}$

In a second regression (second column of Table 6), two sets of explanatory variables are added. One is the share of SOEs in sectoral value added (of the directly reporting industrial enterprises) at the beginning of each time period, weighted across sectors to derive a provincial value, and with coefficients estimated for each time period separately; the other is its $\mathrm{CV}$, where splitting by time period makes no difference to the results. ${ }^{53}$ A clear pattern of the impact of ownership on provincial economic growth, controlling for TOL, emerges: in the first period, 1994-97, state ownership has a significant negative impact on provincial economic growth; by the second period, 1997-00, the impact is still negative but only half the size of the first period's value, as well as less significant, while by the third period all impact has disappeared. Provincial economy-wide TOL has a negative impact on provincial economic growth, which is unexpected. One would expect that the higher the economy-wide total output linkage coefficient, the higher provincial economic growth.

With the mean TOL value approximately equal to the mean SOE share value (unweighted means of 0.54 and 0.64 across provinces and periods), the two variables have approximately the same negative impact on provincial economic growth in the second period, 1997-2000, while in the first period, 1994-97, the SOE share has twice the impact of the TOL. The impact of the SOE share is independent of that of TOL; if the TOL linkage variable (and its

\footnotetext{
52 Throughout all regressions reported in this section, Hainan Province is omitted in the first period (1994-97). If included, its residual constitutes a far outlier that can significantly influence the regression coefficients. The outlier status originates in an unusually low provincial real growth rate of value added with an average annual $5.1 \%$ in the first period. These values contrast with $41 \%, 21 \%$, and $11 \%$ average annual real growth rates in 1992 through 1994.

53 Each of the variables used in the regressions reported in the tables was initially included with coefficients estimated separately for each of the three periods. If the coefficients across the three time periods did not exhibit a marked (and significant) pattern, the regression was re-run without distinction between periods.
} 
$\mathrm{CV}$ ) is omitted (third column of Table 6), the coefficients and significance levels of the SOE share remain unchanged. In all three regressions discussed so far, the large positive size of the constant and period dummies more than makes up for the negative impact of TOL and SOE share.

Switching to TPL instead of TOL (fourth column of Table 6) yields the expected signs: the higher total profit linkage, the higher provincial economic growth. TPL typically explains 2-3 percentage points of provincial economic growth (with an unweighted mean TPL value across provinces and periods of 0.02 ). Because the central region has negative sectoral TPL values in almost all sectors, a dummy variable for the central region's provinces is included in the regression; it has the right sign and size needed to make up for the in this case negative TPL effect. In the fifth regression reported in Table 6 the SOE share is again included. It has the same size and signs as in the case of TOL previously and does little to subtract from the TPL effect; instead, it raises the value of the positive constant and period dummies.

Across all regressions, the CV of TOL, TPL, or the SOE share is insignificant. The degree of equality in the distribution of linkage values (or SOE share values) across sectors makes no difference to provincial economic growth.

The regressions reported so far suggest a positive effect of provincial economy-wide TPL on provincial economic growth; an initially negative effect of state ownership disappears by the third period, 2000-03. The sixth column in Table 6 reports the results when TPL and state ownership are interacted within each province. The newly constructed variable "TPL-SOE," for each province, sums across industrial sectors the (regional) TPL of a sector weighted by that sector's (SOE value added) share in provincial economy-wide industrial SOE value added. A high value of TPL-SOE suggests that SOEs focus on high-linkage sectors. The regression results show that this is indeed the case across all three periods. ${ }^{54}$ On average, the TPL-SOE interaction effect contributes two percentage points to provincial economic growth. (The unweighted mean value of TPL-SOE across provinces and periods is 0.02 .)

When the SOE share is included in the regression (seventh column in Table 6), the TPLSOE interaction effect continues to hold in the second and third period. However, once the TPL is itself included and competes directly with the TPL-SOE interaction effect, the interaction effect between TPL and SOE disappears (eighth and nineth column in Table 6, with and without the SOE share), while the TPL effect is less strong than it is when the TPLSOE interaction effect is excluded. The $\mathrm{R}^{2}$ continues to increase.

In other words, on their own, either TPL or TPL-SOE have the expected consistently significant and positive impact on provincial economic growth. But once they compete directly, multicollinearity appears to erode the individual significance; the pure TPL effect wins out. The pure SOE effect in form of the SOE share continues to exert its negative impact in the first (and possibly second) period before disappearing in the third period.

\section{Tests and variations}

\footnotetext{
54 A coefficient of variation of TPL-SOE is not included because its interpretation appears not straightforward. If included, its coefficient tends to be insignificant except in the third period, when it tends to be negative and significant. (This is independent of if the squared term in the standard deviation is weighted by the SOE share or not.) Inclusion of the coefficient of variation has only a very minor impact on the coefficients of the other variables.
} 
The regression results reported in Table 6 come with residuals that are normally distributed throughout (Jarque-Bera test at the 5\% significance level). Residuals are homoscedastic (White heteroscedasticity test at the 5\% significance level) except in the second regression, which then comes with robust standard errors that are lower than those reported. The Ramsey Reset test with three fitted values does not indicate model misspecification for any of the regressions.

The regressions can be run in a number of variations. First, while SOE share values can only be calculated for the industrial sectors, the TPL can easily be calculated across all sectors within a region (weighting sectoral TPL values by sectoral value added shares). Regressing provincial economic growth on a constant, two time dummies, and the regional economy-wide TPL yields similar results as above with industry TPL values, namely positive TPL coefficients in all three periods, with those of the first two periods significantly different from zero. ${ }^{55}$ The coefficient of variation of regional economy-wide TPL is negative, but significant only in the first period. ${ }^{56}$

Second, the TPL-SOE interaction effect can be augmented by the real growth rate of SOE value added. The TPL-SOE in a growth version is the sum across industrial sectors of regional sectoral TPL times provincial sectoral SOE real growth rate times a sectoral weight in form of "provincial SOE value added in this sector divided by SOE value added in all sectors. ${ }^{57}$ This interaction growth rate also comes with a positive coefficient which, however, is significant in only the second period (and only barely so). Once other control variables are included (SOE share, TPL), as above, all significance vanishes. In other words, in the second period, SOE growth may focus on high-linkage sectors, but the effect is far from strong and disappears once the pure provincial industrial SOE share and the pure provincial industrial TPL are taken into account.

Third, the analysis could also focus on those sectors in a region that come with the highest TPL value. Selecting, in each region, the three industrial sectors with the highest TPL value (marked with a + sign in Table 4 ), the share of these three sectors in provincial industrial value added has a positive impact on provincial economic growth, while the share of SOEs in these three sectors has a negative impact. The growth rate of SOE real value added in these three sectors has practically no impact on provincial economic growth; the same holds if the SOE growth rates of each of the three sectors are weighted by linkage coefficients and SOE value added. If there were a pattern, it is too weak to become apparent

\footnotetext{
55 In these regressions, all 92 observations (31 provinces, of which Chongqing only came into existence in the second period), less Hainan Province in the first period, can be used, whereas the regressions reported in Table 6 are restricted to those combinations of provinces and time periods for which industrial SOE (or directly reporting industrial enterprise) value added data are available. TOL and TPL involve provincial sectoral weights that require value added data on the directly reporting industrial enterprises; similarly, in the calculation of the standard deviation (used in the derivation of the coefficient of variation of TOL or TPL) the squared deviations from the mean are weighted by sectoral value added. Not applying sectoral value added weights when aggregating sectoral TL coefficients to an economy-wide regional TL value makes no qualitative difference to the results.

56 The corresponding regional version of TOL and its coefficient of variation are insignificant.

57 The necessary deflators are national sectoral deflators derived from nominal and real gross output values in the 37-40 industrial sectors, except in 2003 when, lacking real gross output value data, the ex-factory price index is used. (The NBS's procedure for deriving the industrial real growth rate of value added closely matches the procedure chosen here; see Holz, 2006b.) Data sources are the annual Industrial Statistical Yearbook and the annual Statistical Yearbook series.
} 
with the given number of observations. Once the provincial industry TPL value is included in the regression, it dominates all other results. These findings again parallel those above.

Additional variables can be included in the regression, from development level (GDP per employee, share of agriculture in GDP or employment) to capital intensity, schooling, infrastructure (railway network, highway network), and the state share in the always highlinkage sector construction (which is not an industrial sector, and therefore not included in the industrial sector variables used above). Many of these variables are insignificant, and some are potentially endogenous. Including them in the regression does not qualitatively change the core results reported above.

Measures of capital and labor growth are not included because they are intervening as well as endogenous variables. The profit opportunities created by linkages lead to the employment of capital and labor, which then leads to provincial real GDP growth (capital and labor as intervening variables). The profit opportunities created by linkages can also be viewed as leading to new output coming forth, i.e., to provincial real GDP growth, which then implies the purchase of more capital goods and the hiring of more labor (capital and labor as endogenous variables). ${ }^{58}$

An alternative measure of state involvement across sectors is current period investment. If the government were to focus on high-linkage sectors, then the sectoral linkage coefficients should be correlated with the state's sectoral investment values. Provincial-level sectoral investment data by ownership are not available. A proxy could be constructed from changes in asset or fixed asset values, but because of the difficulties in interpreting China's published asset or fixed asset data, and because asset data and value added are typically highly (positively) correlated and value added is already being used here to measure the state's involvement in the economy, that option is not further pursued. ${ }^{59}$

\section{Conclusions}

In answer to the two questions raised previously, first, provincial industrial (or regional economy-wide) TPL has a positive impact on economic growth; the greater the degree of linkage in an economy, the more rapid its economic growth. It is TPL that matters rather than TOL, as suggested by Hirschman but not further pursued in the literature.

Second, state ownership and linkage coefficients are not correlated across sectors; the bivariate analysis suggests that the state does not focus on high-linkage sectors. In multivariate analysis, a variable measuring the extent to which SOEs focus on high-linkage sectors (the TPL-SOE interaction term) exerts a positive effect on provincial economic growth only if provincial industrial TPL is not controlled for. This suggests that the SOE-part of the interaction effect may be very weak or even non-existent.

\footnotetext{
58 Experimenting with the inclusion of a variable measuring capital growth (based on the original value of fixed assets deflated in full at the current year's investment prices), the variable tends to be insignificant or barely significant (with a positive sign).

59 For a discussion of Chinese fixed asset measures see Holz (2006a). For the directly reporting industrial enterprises, the correlation coefficient between asset values and value added across sectors, at the national level in 2005, is 0.86 (Industrial Statistical Yearbook 2006, p. 63).
} 
The regressions show that the state share in the economy has a negative impact on economic growth in the first period, less so or none in the second period, and definitely none in the third period. In other words, an isolated state ownership effect on economic growth is no longer apparent by the third period; Chinese SOEs are no longer dragging down economic growth.

The regressions also show that while the economy-wide degree of TPL matters, the distribution of TPL values across sectors does not. At China's stage of economic development, and given China's history of economic development, it is not the availability or unavailability of extreme profit-creating opportunities (coefficient of variation of TPL) that impacts on economic growth, but the average degree of profit-creating opportunities (TPL).

Similarly, the coefficient of variation of the SOE share in sectoral value added is irrelevant for economic growth. The issue of unbalanced growth in the context of reform period China is one of unbalanced state investment in the economy. The effect of unbalanced state investment on economic growth is captured by the TPL-SOE interaction term, which is significantly positive only as long as the pure TPL effect is not controlled for. That the coefficient of variation of the SOE share in sectoral value added is irrelevant points in the same direction: the SOE share in different sectors, reflecting China's choice of how to distribute state investment across sectors, has no impact on economic growth. ${ }^{60}$

Why does the state not focus on high-linkage sectors? One may wonder to what extent industrial policy in China since the mid-1990s is driven by government decisions vs. profitoriented SOE-internal decisions. Where the government may wish to focus on high-linkage sectors, with possibly large positive externalities, SOE managers may primarily think of their profit. ${ }^{61}$ If SOE investment as profit-seeking rather than profit-creating investment were a correct interpretation, then SOEs do not provide positive externalities via linkage effects. Any justification of state ownership as a generator of economic growth via linkage effects disappears. But at the same time, by the third period SOEs also no longer impede economic growth.

If the state were concerned about making use of high linkage effects but did not want to necessarily exploit them through SOEs, it could also strategically open up high linkage sectors first to non-state enterprises. This would imply that non-state enterprises hold a large share in high linkage sectors, which is what Table 5 indicates across almost all provinces at all times, but only for a few provinces significantly, and without change in significance pattern over time. (The correlation coefficient of non-state enterprises with linkage coefficients across the thirteen industrial sectors is identical in absolute value to that of SOEs, but with opposite sign.)

If the growth of SOEs across sectors were to some extent determined by central policy, the government's sectoral policy needs to be examined further. The tenth Five-Year Plan (2001-05) distinguishes between five groups of industrial sectors. First, military industry remains overwhelmingly state-owned; the military industry may be captured in the regional

\footnotetext{
60 One might want to argue that a particular degree of imbalance in the state share, matching in some way the sectoral distribution of linkage values, is optimal for economic growth. But including the coefficient of variation of the state share in linear and squared form in the regressions also yields insignificant coefficients.

61 If the issue were one of an idealistic central government vs. profit-seeking local governments, the impact of the central government could be small because except for the approximately 150 large central conglomerates, SOEs belong to local governments.
} 
input-output table by the sector "others," a sector that is not a high-linkage sector (Table 3, Table 4). Second, in public goods industries and services, as well as in natural monopolies, the state should hold a controlling stake; utilities, in terms of TPL, are high-linkage sectors (among the top three industrial sectors with the highest linkage within a region) in two regions. Third, state enterprises should continue to hold a dominant position in industries of great importance for the "strength of the nation," such as the petroleum, automobile, telecommunications, machine building, and high technology industries; these sectors match the high-linkage categories more frequently. Fourth, the state should play a driving function in key high technology areas; presumably the most relevant sector in the regional inputoutput table is the electric machinery and electronic communication equipment sector, with a high TOL value in several regions and a high TPL in one region. In other industries, the state is not assigned any specific role. ${ }^{62}$ Overall, the match between linkage coefficients and state industrial policy according to the tenth Five-Year Plan is far from perfect.

As of $2006,80 \%$ of assets held by centrally owned state-owned enterprises are located in just eight industries: petroleum and gas, power, defense, telecommunications, transportation, mining, metallurgy, and machinery. ${ }^{63}$ Again, there is some match with the high-linkage sectors identified in Table 3 and Table 4, but no perfect one. Foods and wood processing, high-linkage sectors in some regions, are definitely not on the SOE list of priorities.

This study is constrained by technical limitations of the method of analysis, by limited data availability, and by data shortcomings. In terms of data availability, it would be most desirable to have a set of provincial input-output tables for a range of years in the reform period, rather than make do with regional data of one year only, but a set of provincial inputoutput tables is not available (and in some provinces an input-output table may not even be compiled). One option, remaining to be explored, is to apply linkage values derived from national input-output tables of various years to provinces; a priori, applying uniform linkage values to all provinces does not necessarily appear promising given the regional variation noted in Table 4. In terms of data shortcomings, the Chinese industry data come with a number of statistical breaks in the second period. But these are likely to be minor, and the distinction between periods in the regressions helps isolate period-specific statistical breaks.

62 For the five-industry classification covered in the Tenth Five-Year Plan see Holz (2003), p. 285.

63 Xinbao (Hong Kong Economic Journal), 18 Dec. 2006, p. 14. 


\section{References}

Chinese names are rendered last name first, with the last name in capitals.

Andreosso-O'Callaghan, Bernadette, and YUE Guoqiang. "Sources of Output Change in China: 1987-1997: Application of a Structural Decomposition Analysis." Applied Economics 34, no. 17 (Nov. 2002): 2227-37. ."Intersectoral Linkages and Key Sectors in China, 1987-1997." Asian Economic Journal 18, no. 2 (June 2004): 165-83.

Bhalla, A.S., and MA Yue. "Sectoral Independence in the Chinese Economy in Comparative Perspective." Applied Economics 22, no. 8 (Aug 1990): 1063-81.

Boucher, Michel. "Some Further Results on the Linkage Hypothesis." The Quarterly Journal of Economics 90, no. 2 (May 1976): 313-8.

Bulmer-Thomas, Victor. Input-Output Analysis in Developing Countries: Sources, Methods and Applications. New York: John Wiley \& Sons Ltd., 1982.

Cella, Guido. "The Input-Output Measurement of Interindustry Linkages." Oxford Bulletin of Economics and Statistics 46, no. 1 (Feb. 1984): 73-84.

Clements, Benedict J. "On the Decomposition and Normalization of Interindustry Linkages." Economic Letters 33, no. 4 (Aug. 1990): 337-40.

Coady, David, and JIE Li. "Changes over Time in Input-Output Coefficients for China." Suntory-Toyota International Centre for Economics and Related Disciplines, The Development Economics Research Programme, London School of Economics, October 1993.

Diamond, J. "Key Sectors in Some Underdeveloped Countries: A Comment." Kyklos 29, no. 4 (1976): 762-4.

Dietzenbacher, Erik. "In Vindication of the Ghosh Model: A Reinterpretation As a Price Model." Journal of Regional Science 37, no. 4 (Nov. 1997): 629-51.

Fifty-five Years. Xin zhongguo wushiwu nian tongji ziliao huibian (Compendium of Fifty-five Years of Statistics of the New China). National Bureau of Statistics. Beijing: Zhongguo tongji chubanshe, 2005.

Heimler, Alberto. "Linkages and Vertical Integration in the Chinese Economy." The Review of Economics and Statistics LXXIII, no. 2 (May 1991): 261-7.

Hewings, Geoffrey J.D. "The Empirical Identification of Key Sectors in an Economy: A Regional Perspective." The Developing Economies 20, no. 2 (June 1982): 173-95.

Hirschman, Albert O. The Strategy of Economic Development. New Haven: Yale University Press, 1958.

Hirschman, Albert O. “A Dissenter's Confession: 'The Strategy of Economic Development' Revisited," in Gerald M. Meier and Dudley Seers, Pioneers in Development. New York: Oxford University Press, 1984, pp. 87-111.

Holz, Carsten A. "Long Live China's State-owned Enterprises: Deflating the Myth of Poor Financial Performance.” Journal of Asian Economics 13, no. 4 (July/August 2002): 493 529.

China's Industrial State-owned Enterprises: Between Profitability and Bankruptcy. Singapore: World Scientific, 2003. 85 . "New Capital Estimates for China." China Economic Review 17, no. 2 (2006a): 142-

."Measuring Chinese Productivity Growth, 1952-2005." Mimeo, 22 July 2006b, Hong Kong University of Science \& Technology, http://ihome.ust.hk/ socholz.

Holz, Carsten A., and Yi-min Lin. "The 1997-98 Break in Industrial Statistics: Facts and Appraisal.” China Economic Review 12, no. 4 (2001): 303-316. 
Ichimura, Shinichi, and WANG Hui-Jiong. Interregional Input-Output Analysis of the Chinese Economy. River Edge, New Jersey: World Scientific, 2003.

Imbs, Jean, and Romain Wacziarg. "Stages of Diversification." The American Economic

Review 93, no. 1 (March 2003): 63-86.

Industrial Yearbook. Zhongguo gongye jingji tongji nianjian (China Industrial Economy

Statistical Yearbook). Beijing: Zhongguo tongji chubanshe, various years.

Input-output table (IO table).

1981. State Planning Commission and State Statistical Bureau. Input-Output Tables of China, 1981. Beijing: China Statistical Information and Consultancy Service Centre, 1987.

1987 [1990, 1992, 1995, 1997, 2002]. National Bureau of Statistics. Zhongguo touru chanchu biao [date] (China's input-output table [date]). Beijing: Zhongguo tongji chubanshe, [publication dates:] 1991 [1993, 1996, 1997, 1999, 2006].

Jefferson, Gary H., Thomas G. Rawski, WANG Li, and ZHENG Yuxin. "Ownership, Productivity Change, and Financial Performance in Chinese Industry." Journal of Comparative Economics 28, no. 4 (Dec. 2000): 786-813.

Jefferson, Gary H., and SU Jian. "Privatization and Restructuring in China: Evidence from Shareholding Ownership, 1995-2001." Journal of Comparative Economics 34, no. 1 (March 2006): 146-66.

Jones, Leroy P. "The Measurement of Hirschmanian Linkages." The Quarterly Journal of Economics 90, no. 2 (May 1976): 323-33.

Krugman, Paul. "The Fall and Rise of Development Economics," in Lloyd Rodwin and Donald A. Schon (eds), Rethinking the Development Experience: Essays Provoked by the Work of Albert O. Hirschman, Washington (D.C.): Brookings Institution, 1994, pp. 39-58.

Laumas, Prem S. "The Weighting Problem in Testing the Linkage Hypothesis." The Quarterly Journal of Economics 90, no. 2 (May 1976): 308-12.

LI Zhenzhong. Jihua jingjixue (xiudingben) (Planned Economy (revised edition)). Beijing: Zhongguo renmin daxue chubanshe, 1988.

LI Qiang. Dangai zhongguo touru chanchu yingyong yu fazhan (Applications and development of input-output analysis in current China). Beijing: Zhongguo tongji chubanshe, 1992.

LI Qiang and XUE Tiandong (eds.). Zhongguo jingji fazhan bumen fenxi jian xinbian kebi jia touru chanchu xuliebiao (Sectoral analysis of China's economic development and series of new input-output tables at comparable prices). Beijing: Zhongguo tongji chubanshe, 1998.

LIN, Justin Yifu. "Development Strategy, Viability, and Economic Convergence." Economic Development and Cultural Change 51, no. 2 (Jan. 2003): 276-308.

LIN, Justin Yifu, CAI Fang, and LI Zhou. "Competition, Policy Burdens, and State-Owned Enterprise Reform.” American Economic Review 88, no. 2 (May 1998): 422-27. . The China Miracle: Development Strategy and Economic Reform. Hong Kong: The Chinese University Press, 2003.

LIU Xiaoyu. Zhongguo chanye jiegou de touru chanchu fenxi (Input-output analysis of China's industrial structure). Beijing: Jingji guanli chubanshe, 2003.

McGilvray, James W. "Linkages, Key Sectors, and Development Strategy," Chapter 4 in Wassily Leontieff (ed.), Structure, System and Economic Policy, Cambridge: Cambridge University Press, 1977, pp. 49-56.

Miller, Ronald E., and Peter D. Blair. Input-Output Analysis: Foundations and Extensions. Englewood Cliffs, NJ: Prentice-Hall, 1985. 
Miller, Ronald E., and Michael L. Lahr. "A Taxonomy of Extractions," Chapter 21 in Ronald E. Miler and Michael L. Lahr (eds.), Regional Science Perspectives in Economic Analysis, Amsterdam: Elsevier, 2001, pp. 407-41.

NBS (National Bureau of Statistics). Zhongguo niandu guonei shengchan zongzhi jisuan fangfa (Calculation Method for China's Annual GDP). Beijing: Zhongguo tongji chubanshe, 1997.

Nugent, Jeffrey B., and Yotopoulos, Pan A. "Morphology of Growth: The Effects of Country Size, Structural Characteristics and Linkages." Journal of Development Economics 10, no. 3 (June 1982): 279-95.

Polenske, Karen R., and CHEN Xikang. Chinese Economic Planning and Input-Output Analysis. Hong Kong: Oxford University Press, 1991.

Riedel, James. "A Balanced-Growth Version of the Linkage Hypothesis: A Comment." The Quarterly Journal of Economics 90, no. 2 (May 1976): 319-22.

Roberts, Barbara M. "The Sequence of Privatisation-The Case of Poland." British Review of Economic Issues 15, no. 37 (Oct. 1993): 97-108.

Rodrik, Dani. "Industrial Development: Stylized Facts and Policies." Mimeo, August 2006(a). John F. Kennedy School of Government, Harvard University.

Rodrik, Dani. "Doomed to Choose: Industrial Policy As Predicament." Mimeo, September 2006(b). John F. Kennedy School of Government, Harvard University.

Rosenstein-Rodan, Paul N. "Natura Facit Saltum", pp. 207-21 in Gerald Meier and Dudley Seers (eds.), Pioneers in Development. Oxford: Oxford University Press, 1984.

Sachs, Jeffrey D. Interview with Harvard China Review 1, no. 1 (Summer 1998): 12-29.

SIC (State Information Center guojia xinxi zhongxin). Zhongguo quyu jian touru chanchu biao (Inter-regional input-output table for China). Beijing: Shehui kewue wenxian chubanshe, 2005.

Sonis, Michael, Joaquim J.M. Guilhoto, Geoffrey J.D. Hewings, and Eduardo B. Martins. "Linkages, Key Sectors, and Structural Change: Some New Perspectives." The Developing Economies 33, no. 3 (Sept. 1995): 233-70.

Sonis, Michael, Geoffrey J.D. Hewings, and Eduardo Haddad. "A Typology of Propagation of Changes on the Structure of a Multiregional Economic System: The Case of the European Union, 1975-1985." Annals of Regional Science 30, no. 4 (Dec. 1996): 391-408.

Thoburn, J.T. "Exports and the Malaysian Engineering Industry: A Case Study of Backward Linkage." Oxford Bulletin of Economics and Statistics 35, no. 2 (1973): 91-117.

World Bank. World Development Report 1996: From Plan to Market. New York: Oxford University Press, 1996.

XU Xianchun and LIU Qiyun (eds.). Zhongguo touru chanchu fenxi yingyong lunwen jingcui (Essays on the application of input-output analysis in China). Beijing: Zhongguo tongji chubanshe, 2004.

Yotopoulos, Pan A., and Lawrence J. Lau. "A Test for Balanced and Unbalanced Growth." Review of Economics and Statistics 52, no. 4 (Nov. 1970): 376-84. "The Balanced-Unbalanced Growth Controversy Revisited." The Review of Economics and Statistics 57, no. 4 (Nov. 1975): 516f-7.

Yotopoulos, Pan A., and Jeffrey B. Nugent. "A Balanced-Growth Version of the Linkage Hypothesis: A Test." The Quarterly Journal of Economics 87, no. 2 (May 1973): 157-71. ."In Defense of a Test of the Linkage Hypothesis." The Quarterly Journal of Economics 90, no. 2 (May 1976): 334-43.

Yusuf, Shahid, Kaoru Nabeshima, and Dwight H. Perkins. Under New Ownership: Privatizing China's State-owned Enterprises. Washington, DC and Palo Alto: The World Bank and Stanford University Press, 2006. 


\begin{tabular}{|c|c|c|c|c|c|c|c|c|c|c|c|c|}
\hline & \multirow{2}{*}{\multicolumn{4}{|c|}{$\begin{array}{l}\text { Intermediate purchases } \\
\text { of sector } j\end{array}$}} & \multirow{3}{*}{$\begin{array}{c}\text { Sum } \\
\text { interm. } \\
\text { sales }\end{array}$} & \multirow{3}{*}{ Con. } & \multicolumn{3}{|c|}{ Final demand } & \multirow{3}{*}{$\begin{array}{l}\text { Sum } \\
\text { final } \\
\text { dem. }\end{array}$} & \multirow{3}{*}{$\begin{array}{l}\text { Gross } \\
\text { output } \\
\text { value }\end{array}$} \\
\hline & & & & & & & & Inv. & Exp. & Imports & & \\
\hline & & 1 & 2 & $\ldots$ & $\mathrm{n}$ & & & & & (neg.) & & \\
\hline Intermed. & 1 & $\mathrm{X}_{11}$ & $\mathrm{X}_{12}$ & $\ldots$ & $\mathrm{X}_{1 \mathrm{n}}$ & $\mathrm{U}_{1}$ & $\mathrm{C}_{1}$ & $\mathrm{I}_{1}$ & $\mathrm{E}_{1}$ & $\mathrm{M}_{1}$ & $\mathrm{Y}_{1}$ & $\mathrm{X}_{1}$ \\
\hline \multirow{2}{*}{$\begin{array}{l}\text { sales of } \\
\text { sector i }\end{array}$} & 2 & $\mathrm{X}_{21}$ & $\mathrm{X}_{22}$ & $\ldots$ & $X_{2 n}$ & $\mathrm{U}_{2}$ & $\mathrm{C}_{2}$ & $\mathrm{I}_{2}$ & $\mathrm{E}_{2}$ & $\mathrm{M}_{2}$ & $\mathrm{Y}_{2}$ & $\mathrm{X}_{2}$ \\
\hline & n & & & $\begin{array}{l}\cdots \\
\ldots\end{array}$ & & & $\mathrm{C}_{\mathrm{n}}$ & $\mathrm{I}_{\mathrm{n}}$ & $\begin{array}{l}\cdots \\
\mathrm{E}_{\mathrm{n}}\end{array}$ & $\mathrm{M}_{\mathrm{n}}$ & & $X_{n}$ \\
\hline \multicolumn{2}{|c|}{ Sum int. purch. } & $\mathrm{V}_{1}$ & $\mathrm{~V}_{2}$ & $\ldots$ & $\mathrm{V}_{\mathrm{n}}$ & & & & & & & \\
\hline \multirow{4}{*}{$\begin{array}{l}\text { Primary } \\
\text { inputs }\end{array}$} & $\mathrm{L}$ & $\mathrm{L}_{1}$ & $\mathrm{~L}_{2}$ & $\ldots$ & $\mathrm{L}_{\mathrm{n}}$ & & & & & & & \\
\hline & D & $\mathrm{D}_{1}$ & $\mathrm{D}_{2}$ & $\ldots$ & $\mathrm{D}_{\mathrm{n}}$ & & & & & & & \\
\hline & T & $\mathrm{T}_{1}$ & $\mathrm{~T}_{2}$ & $\ldots$ & $T_{n}$ & & & & & & & \\
\hline & $\mathrm{S}$ & $\mathrm{S}_{1}$ & $\mathrm{~S}_{2}$ & $\ldots$ & $\mathrm{S}_{\mathrm{n}}$ & & & & & & & \\
\hline \multicolumn{2}{|c|}{ Sum prim. inp. } & $\mathrm{W}_{1}$ & $\mathrm{~W}_{2}$ & $\cdots$ & $\mathrm{W}_{\mathrm{n}}$ & & & & & & & \\
\hline \multicolumn{2}{|l|}{ Gr. outp. val. } & $\mathrm{X}_{1}$ & $\mathrm{X}_{2}$ & & $\mathrm{X}$ & & & & & & & \\
\hline
\end{tabular}

L: labor remuneration; D: depreciation; T: net taxes on production; S: operating surplus.

Con.: consumption; Inv.: investment (gross fixed capital formation); Exp.: exports.

$\mathrm{W}$ is value added. The sum of sectoral value added equals the sum of final demand (income approach GDP equals expenditure approach GDP).

Figure 1. Input-Output Table 
Table 1. Linkage Indicators of Individual Sectors

\begin{tabular}{|c|c|c|}
\hline 1. & Leontief inverse & $\begin{array}{l}\operatorname{BL}(1)_{j}=\sum_{i} X_{i j} / X_{j}=\sum_{i} a_{i j} \\
\operatorname{FL}(1)_{i}=\sum_{j} X_{i j} / X_{i}=\sum_{j} b_{i j} \\
\operatorname{BL}(2)_{j}=\sum_{i} \alpha_{i j}=j^{\text {th }} \text { element of } e^{\prime}(I-A)^{-1}\end{array}$ \\
\hline & Gosh inverse & $\mathrm{FL}(2)_{\mathrm{i}}=\sum_{\mathrm{j}} \beta_{\mathrm{ij}}=\mathrm{i}^{\text {th }}$ element of $(\mathrm{I}-\mathrm{B})^{-1} \mathrm{e}$ \\
\hline 3. & Cai/Leung (2004) & $\begin{array}{l}\mathrm{LSD}=\operatorname{BL}(3)_{\mathrm{i}}=1+\mathbf{e}^{\prime}\left(\mathbf{I}-\mathbf{A}_{\mathrm{jj}}\right)^{-1} \mathbf{A}_{\mathrm{ji}} \\
\mathrm{GSD}=\operatorname{FL}(3)_{\mathrm{i}}=1+\mathbf{B}_{\mathrm{ij}}\left(\mathbf{I}-\mathbf{B}_{\mathrm{jj}}\right)^{-1} \mathbf{e}\end{array}$ \\
\hline 4. & $\begin{array}{l}\text { Index of vertical } \\
\text { integration } \\
\quad \text { (Heimler, 1991) }\end{array}$ & $\begin{array}{c}\mathrm{INT}_{\mathrm{i}}=\left[\mathbf{v}^{\prime}\left(\mathbf{I}-\mathbf{A}_{\mathrm{jj}}\right)^{-1} \mathbf{A}_{\mathrm{ji}} \mathrm{X}_{\mathrm{i}}\right] / \mathrm{VA}_{\mathrm{i}}, \text { where } \\
\mathrm{v} \text { is a vector of sectoral ratios of value added to gross } \\
\text { output value, and } \mathrm{VA}_{\mathrm{i}} \text { is value added of sector } \mathrm{i}\end{array}$ \\
\hline 5. & $\begin{array}{l}\text { Total linkage effect: } \\
\text { Leontief - HEM }\end{array}$ & $\begin{array}{l}\mathbf{e}^{\prime}\left(\mathbf{x}_{\mathrm{j}}-\mathbf{x}_{\mathrm{j}}^{\mathrm{R}}\right)=\mathbf{e}^{\prime}\left(\boldsymbol{\alpha}_{\mathrm{jj}} \mathbf{A}_{\mathrm{ji}} \mathbf{H} \mathbf{y}_{\mathrm{i}}\right)+\mathbf{e}^{\prime}\left(\boldsymbol{\alpha}_{\mathrm{jj}} \mathbf{A}_{\mathrm{ji}} \mathbf{H} \mathbf{A}_{\mathrm{ij}} \boldsymbol{\alpha}_{\mathrm{jj}} \mathbf{y}_{\mathrm{j}}\right) \\
\quad \text { where } \boldsymbol{\alpha}_{\mathrm{jj}}=\left(\mathbf{I}-\mathbf{A}_{\mathrm{jj}}\right)^{-1} \text {, and } \mathbf{H}=\left(\mathbf{I}-\mathbf{A}_{\mathrm{ii}}-\mathbf{A}_{\mathrm{ij}} \boldsymbol{\alpha}_{\mathrm{jj}} \mathbf{A}_{\mathrm{ji}}\right)^{-1} \\
\mathrm{TL}_{\mathrm{i}}=\mathbf{e}^{\prime}\left(\mathbf{x}_{\mathrm{j}}-\mathbf{x}_{\mathrm{j}}^{\mathrm{R}}\right) / \mathrm{X}_{\mathrm{i}}\end{array}$ \\
\hline
\end{tabular}

share of intermediate purchases in inputs of sector $\mathrm{j}$

share of intermediate sales in output of sector $i$

total (economy-wide) output change due to one-unit change in final demand for sector $\mathrm{j}$

total output (input) change due to one-unit change in value of primary inputs into sector $i$

total output change due to one-unit change in output of sector $i$ total output change due to one-unit change in input of sector $i$ value added generated by sector i, outside sector i (in sector[s] $\mathrm{j})$, per unit of value added in sector $\mathrm{i}$

absolute reduction in output outside sector $i$ (in sector[s] j) if sector $\mathrm{i}$ is eliminated

total output change outside sector $\mathrm{i}$ (in sector $[\mathrm{s}] \mathrm{j}$ ) due to oneunit output change in sector $i$

"Output" refers to gross output value; "total output" refers to gross output value economy-wide.

"e" denotes a column vector of ones.

The A (and similarly B) matrix is partitioned into row and column i vs. all other rows and columns (block) j, i.e., $\mathbf{A}=\left[\mathbf{A}_{\mathrm{ii}} \mathbf{A}_{\mathrm{ij}}, \mathbf{A}_{\mathrm{ji}} \mathbf{A}_{\mathrm{jj}}\right]$.

For the definition of all other variables see the text.

For the derivation of the LSD and GSD see Cai and Leung (2004). The authors point out that, following Miller and Blair (1985, p. 328), a simpler way to calculate LSD is to obtain a modified Leontief inverse. The modified Leontief inverse is obtained by dividing each element $\alpha_{\mathrm{ij}}$ in $(\mathbf{I}-\mathbf{A})^{-1}$ by the diagonal element in its column $\left(\alpha_{\mathrm{ii}}\right)$ to obtain $\left(\mathbf{I}-\mathbf{A}^{*}\right)^{-1}$ and then calculating the $\mathrm{i}^{\text {th }}$ column sum of $\left(\mathbf{I}-\mathbf{A}^{*}\right)^{-1}$. Similarly for GSD, where each element $\beta_{\mathrm{ij}}$ of the Gosh inverse $(\mathbf{I}-\mathbf{B})^{-1}$ is divided by the diagonal element in its row, $\beta_{\mathrm{ii}}$, and GSD then equals the $\mathrm{i}^{\text {th }}$ row sum of $\left(\mathbf{I}-\mathbf{B}^{*}\right)^{-1}$.

For the derivation of the total linkage following the hypothetical extraction method (HEM) using the Leontief inverse, see Miller and Lahr 2001 (pp. 411-4). The formula presented here follows from inverting a partitioned matrix, where $\mathbf{A}$ in the Leontief inverse (I-A) $)^{-1}$ is partitioned into (any) first sector i to be eliminated vs. all other sectors, and $\mathbf{A}_{\mathrm{ii}}=\mathbf{A}_{\mathrm{ij}}=\mathbf{A}_{\mathrm{ji}}=0$ in the scenario " $\mathbf{x}_{\mathrm{j}}^{\mathrm{R}}$." 
Table 2. Correlation Coefficients Across 17 Sectors (Region Beijing-Tianjin, 1997)

\begin{tabular}{|c|c|c|c|c|c|c|c|c|}
\hline & $\overline{\mathrm{BL}(1)}$ & $\overline{F L(1)}$ & $\overline{\mathrm{BL}(2)}$ & $\overline{\mathrm{FL}(2)}$ & LSD & $\overline{G S D}$ & INT & $\overline{\mathrm{TL}}$ \\
\hline \multicolumn{9}{|c|}{ Output-linkage indicators } \\
\hline $\mathrm{BL}(1)$ & 1.000 & $*_{-} 0.448$ & $* * * 0.970$ & $* 0.432$ & 0.199 & $* * *_{-} 0.724$ & $* * * 0.785$ & 0.267 \\
\hline $\mathrm{FL}(1)$ & & 1.000 & -0.373 & -0.335 & -0.411 & $* * * 0.868$ & $* *-0.518$ & $* * *-0.690$ \\
\hline BL(2) & & & 1.000 & 0.392 & 0.154 & $* * *-0.649$ & $* * * 0.689$ & 0.212 \\
\hline $\mathrm{FL}(2)$ & & & & 1.000 & -0.306 & $* *-0.502$ & 0.130 & -0.125 \\
\hline LSD & & & & & 1.000 & -0.169 & $* * 0.582$ & $* * * 0.905$ \\
\hline GSD & & & & & & 1.000 & $* *-0.582$ & $*-0.472$ \\
\hline INT & & & & & & & 1.000 & $* * 0.566$ \\
\hline TL & & & & & & & & 1.000 \\
\hline \multicolumn{9}{|c|}{ Profit-linkage indicators } \\
\hline \multicolumn{9}{|l|}{$\mathrm{BL}(1)$} \\
\hline $\operatorname{FL}(1)$ & & 1.000 & 0.240 & -0.196 & 0.343 & $* * 0.605$ & -0.300 & -0.141 \\
\hline $\mathrm{BL}(2)$ & & & 1.000 & $* * 0.557$ & $* * * 0.974$ & $* * * 0.892$ & $* * *-0.607$ & -0.248 \\
\hline $\mathrm{FL}(2)$ & & & & 1.000 & $* 0.416$ & 0.304 & -0.347 & -0.346 \\
\hline LSD & & & & & 1.000 & $* * * 0.931$ & $* *_{-} 0.568$ & -0.146 \\
\hline GSD & & & & & & 1.000 & $* * *-0.678$ & -0.334 \\
\hline INT & & & & & & & 1.000 & $* * * 0.641$ \\
\hline TL & & & & & & & & 1.000 \\
\hline \multirow{2}{*}{\multicolumn{9}{|c|}{ Same type of linkage measure, output- vs. profit-linkage }} \\
\hline & & & $* * *-0.806$ & $* * * 0.629$ & -0.047 & $* * * 0.730$ & $* * * 0.925$ & $* * * 0.823$ \\
\hline
\end{tabular}

For the meaning of the individual column and row labels see Table 1.

BL(1) values in the case of profit-linkage coefficients are not meaningful; the (output) linkage coefficient is the share of intermediate purchases in inputs of sector $\mathrm{j}$, with no possibility to transform this coefficient into a profit measure.

Significance levels: * $10 \%, * * 5 \%, * * * 1 \%$.

Source: manipulation of data from SIC (2005). 
Table 3. Total Output-Linkage Coefficients, 17 Sectors, 8 Regions (1997)

\begin{tabular}{|c|c|c|c|c|c|c|c|c|}
\hline & $\begin{array}{l}\text { North- } \\
\text { east }\end{array}$ & $\begin{array}{l}\text { Beijing- } \\
\text { Tianjin }\end{array}$ & North & East & South & Central & $\begin{array}{l}\text { North- } \\
\text { west }\end{array}$ & $\begin{array}{c}\text { South- } \\
\text { west }\end{array}$ \\
\hline 1. Agric. & 0.500 & 0.465 & 0.424 & 0.477 & 0.344 & 0.389 & 0.270 & 0.286 \\
\hline 2. Mining & 0.417 & 0.117 & 0.169 & 0.314 & 0.272 & 0.156 & 0.185 & 0.418 \\
\hline 3. Foods & ${ }^{+} 0.943$ & 0.678 & 0.712 & ${ }^{+} 0.799$ & 0.745 & ${ }^{+} 0.798$ & ${ }^{+} 0.736$ & 0.693 \\
\hline 4. Textiles & 0.818 & 0.686 & 0.619 & 0.488 & 0.491 & 0.560 & ${ }^{+} 0.660$ & ${ }^{+} 0.788$ \\
\hline 5. Wood & 0.798 & ${ }^{+} 0.923$ & ${ }^{+} 0.837$ & 0.640 & ${ }^{+} 0.769$ & 0.581 & 0.558 & 0.665 \\
\hline 6. Paper & 0.749 & 0.602 & 0.652 & 0.647 & 0.748 & 0.535 & 0.509 & 0.593 \\
\hline 7. Chemicals & 0.595 & 0.312 & 0.324 & 0.291 & 0.387 & 0.348 & 0.505 & 0.556 \\
\hline 8. Non-metals & 0.769 & 0.833 & 0.715 & 0.714 & 0.813 & 0.624 & 0.564 & 0.881 \\
\hline 9. Metals & 0.513 & 0.317 & 0.258 & 0.351 & 0.427 & 0.221 & 0.288 & 0.512 \\
\hline 10. Machinery & ${ }^{+} 1.021$ & +0.946 & 0.485 & ${ }^{+} 0.836$ & ${ }^{+} 0.794$ & ${ }^{+} 0.714$ & +0.615 & +0.913 \\
\hline 11. Transp. eq. & 0.868 & 0.702 & +0.966 & ${ }^{+} 0.809$ & 0.739 & 0.656 & 0.541 & 0.613 \\
\hline 12. Electronic & ${ }^{+} 0.920$ & 0.351 & ${ }^{+} 0.851$ & 0.725 & 0.618 & ${ }^{+} 0.786$ & 0.551 & 0.646 \\
\hline 13. Other & 0.893 & 0.633 & 0.662 & 0.773 & 0.555 & 0.400 & 0.394 & 0.760 \\
\hline 14. Utilities & 0.790 & 0.467 & 0.292 & 0.496 & 0.494 & 0.347 & 0.433 & 0.582 \\
\hline 15. Construction & 1.517 & 1.291 & 1.406 & 1.361 & 1.112 & 1.407 & 0.953 & 1.246 \\
\hline 16. Commerce & 0.684 & 0.596 & 0.415 & 0.530 & 0.542 & 0.364 & 0.362 & 0.482 \\
\hline 17. Other serv. & 1.022 & 0.362 & 0.461 & 0.568 & 0.512 & 0.502 & 0.396 & 0.449 \\
\hline Average & 0.813 & 0.605 & 0.603 & 0.636 & 0.609 & 0.552 & 0.501 & 0.652 \\
\hline $\mathrm{CV}$ & 0.304 & 0.463 & 0.494 & 0.389 & 0.338 & 0.506 & 0.360 & 0.333 \\
\hline Weighted Ave.^ & 0.747 & 0.520 & 0.524 & 0.609 & 0.552 & 0.508 & 0.424 & 0.528 \\
\hline Weighted $\mathrm{CV}^{\wedge}$ & 0.389 & 0.529 & 0.536 & 0.417 & 0.378 & 0.551 & 0.483 & 0.493 \\
\hline \multicolumn{9}{|c|}{ Correlation coefficients: all signific. at the $0.1 \%$ level, except the North-Southwest value (1\% level) } \\
\hline Northeast & 1.00 & 0.741 & 0.791 & 0.904 & 0.814 & 0.898 & 0.826 & 0.799 \\
\hline Beijing-T. & & 1.000 & 0.770 & 0.834 & 0.892 & 0.787 & 0.794 & 0.834 \\
\hline North & & & 1.000 & 0.889 & 0.854 & 0.901 & 0.801 & 0.722 \\
\hline East & & & & 1.000 & 0.906 & 0.923 & 0.785 & 0.812 \\
\hline South & & & & & 1.000 & 0.876 & 0.838 & 0.826 \\
\hline Central & & & & & & 1.000 & 0.909 & 0.806 \\
\hline Northwest & & & & & & & 1.000 & 0.852 \\
\hline Southwest & & & & & & & & 1.000 \\
\hline
\end{tabular}

The linkage indicator used is the TL (TOL) as defined in Table 1.

Superscript + denotes the three sectors within industry (industry comprises sectors 2 through 14) with the highest linkage value.

Italics mark those non-industrial sectors with a linkage value at least as high as the third-highest linkage value in industry.

$\wedge$ Weights consist of sectoral value added. In the calculation of the standard deviation (used in the coefficient of variation), the squared deviation of a particular sector's linkage coefficient from the weighted average linkage coefficient was weighted with the sector's share in overall value added. The complete labels of the individual sectors are: (1) 农业 (agriculture), (2) 采选业 (mining), (3) 食 品制造及烟草加工业 (food processing and tobacco), (4) 纺织服装业 (textiles and apparel), (5) 木材 加工及家具制造业 (wood processing and furniture manufacturing), (6) 造纸印刷及文教用品制造 业 (paper manufacturing, printing, and cultural articles), (7) 化学工业 (chemicals), (8), 非金属矿物 制品业 (processing of non-metal minerals), (9) 金属冶炼及制品业 (smelting and pressing of metals), (10) 机械工业 (machinery), (11) 交通运输设备制造业 (transport equipment), (12) 电气机械及电子 通信设备制造业 (electric machinery and electronic communication equipment), (13) 其他制造业 (other manufacturing), (14)电力蒸气热水, 煤气自来水生产供应业 (production and supply of electric power, steam, hot water, gas, and running water), (15) 建筑业 (construction), (16) 商业, 运 输业 (commerce and transportation), (17) 其他服务业 other services.

Source: manipulation of data from SIC (2005). 
Table 4. Total Profit-Linkage Coefficients, 17 Sectors, 8 Regions (1997)

\begin{tabular}{|c|c|c|c|c|c|c|c|c|}
\hline & $\begin{array}{l}\text { North- } \\
\text { east }\end{array}$ & $\begin{array}{l}\text { Beijing- } \\
\text { Tianjin }\end{array}$ & North & East & South & Central & $\begin{array}{c}\text { North- } \\
\text { west }\end{array}$ & $\begin{array}{c}\text { South- } \\
\text { west }\end{array}$ \\
\hline 1. Agric. & 0.019 & 0.030 & 0.037 & 0.037 & 0.020 & -0.005 & 0.017 & 0.015 \\
\hline 2. Mining & 0.010 & 0.009 & 0.012 & 0.025 & 0.016 & ${ }^{+}-0.002$ & 0.011 & 0.019 \\
\hline 3. Foods & 0.052 & ${ }^{+} 0.063$ & 0.051 & 0.056 & 0.041 & -0.035 & 0.072 & 0.020 \\
\hline 4. Textiles & 0.038 & 0.051 & 0.048 & 0.039 & 0.031 & -0.015 & 0.063 & ${ }^{+} 0.032$ \\
\hline 5. Wood & +0.047 & ${ }^{+} 0.057$ & ${ }^{+} 0.067$ & 0.048 & ${ }^{+} 0.046$ & -0.011 & 0.042 & 0.024 \\
\hline 6. Paper & 0.038 & 0.033 & 0.049 & 0.051 & 0.041 & -0.008 & 0.043 & 0.026 \\
\hline 7. Chemicals & 0.047 & 0.028 & 0.021 & 0.022 & 0.024 & -0.006 & 0.050 & 0.023 \\
\hline 8. Non-metals & 0.039 & ${ }^{+} 0.053$ & 0.049 & ${ }^{+} 0.058$ & ${ }^{+} 0.056$ & -0.008 & 0.042 & +0.036 \\
\hline 9. Metals & 0.030 & 0.024 & 0.018 & 0.030 & 0.030 & ${ }^{+}-0.002$ & 0.023 & 0.025 \\
\hline 10. Machinery & 0.035 & 0.043 & 0.033 & ${ }^{+} 0.058$ & ${ }^{+} 0.046$ & -0.012 & 0.037 & +0.037 \\
\hline 11. Trar & 0.026 & 0.031 & ${ }^{+} 0.067$ & ${ }^{+} 0.058$ & 0.039 & -0.013 & 0.025 & 0.024 \\
\hline 12. Electro & 0.031 & 0.023 & ${ }^{+} 0.060$ & 0.053 & 0.034 & -0.014 & 0.033 & 0.025 \\
\hline 13. Other & 0.027 & 0.040 & 0.042 & 0.050 & 0.025 & -0.010 & 0.024 & 0.029 \\
\hline 14. Utilities & 0.052 & 0.031 & 0.021 & 0.040 & 0.030 & ${ }^{+}-0.006$ & 0.038 & 0.021 \\
\hline 15. Con & 0.062 & 0.069 & 0.094 & 0.094 & 0.050 & -0.021 & 0.052 & 0.043 \\
\hline 16. $\mathrm{C}$ & 0.012 & 0.061 & 0.032 & 0.047 & 0.036 & -0.001 & 0.019 & 0.033 \\
\hline 17. Other & 0.052 & 0.014 & 0.033 & 0.037 & 0.028 & -0.011 & 0.030 & 0.016 \\
\hline Average & 0.036 & 39 & 0.043 & 0.0 & 0.035 & -0.011 & 0.036 & 0.026 \\
\hline $\mathrm{CV}$ & 0.395 & 2 & 0.475 & 0.3 & 0.303 & -0.743 & 0.440 & 0.286 \\
\hline Weight & 0.032 & 0.032 & 0.039 & 0.045 & 0.031 & -0.009 & 0.030 & 0.022 \\
\hline Weigh & 0.543 & 0.627 & 0.485 & 0.372 & 0.307 & -0.862 & 0.542 & 0.401 \\
\hline Weig & 0.018 & 0.025 & 0.041 & 0.044 & 0.031 & -0.009 & 0.026 & 0.022 \\
\hline Weighted CV^^ & 0.833 & 3 & 0.516 & 0.379 & 0.274 & -0.979 & 0.652 & 0.364 \\
\hline \multicolumn{9}{|l|}{ Correlation } \\
\hline Northeast & 1.000 & 0.335 & 0.411 & 0.390 & $* 0.457$ & $* *-0.577$ & $* * * * 0.755$ & 0.167 \\
\hline Beijing-T. & & 1.000 & $* * 0.595$ & $* * * 0.658$ & $* * * 0.695$ & $* *-0.500$ & $* * 0.562$ & $* * 0.657$ \\
\hline North & & & 1.000 & $* * * * 0.851$ & $* * * 0.660$ & $* * *-0.607$ & 0.408 & $* 0.470$ \\
\hline East & & & & 1.000 & $* * * * 0.766$ & $* *_{-} 0.571$ & 0.332 & $* * * 0.680$ \\
\hline South & & & & & 1.000 & $*_{-} 0.421$ & $* 0.482$ & $* * * 0.677$ \\
\hline Central & & & & & & 1.000 & $* * * *-0.748$ & -0.136 \\
\hline Northwe & & & & & & & 1.000 & 0.284 \\
\hline Southwest & & & & & & & & 1.000 \\
\hline
\end{tabular}

The linkage indicator used is the total profit-linkage (TPL) indicator derived from the TL (TOL) in Table 1 as explained in the text.

The notes to Table 3, except on the significance of the correlation coefficients, apply in full to this table here.

Significance levels: $* 10 \%, * * 5 \%, * * * 1 \%, * * * * 0.1 \%$.

$\wedge$ Weights consist of sectoral operating surplus. (Also see notes to previous table on "^..)

Source: manipulation of data from SIC (2005). 
Table 5. Correlation Coefficients Across 13 Industrial Sectors, Total Linkage Vs. State Share

\begin{tabular}{|c|c|c|c|c|c|c|c|c|}
\hline & \multicolumn{4}{|c|}{ Total output-linkage } & \multicolumn{4}{|c|}{ Total profit-linkage } \\
\hline & 1994 & 1997 & 2000 & 2003 & 1994 & 1997 & 2000 & 2003 \\
\hline Beijing & $*_{-0.481}$ & & & -0.459 & -0.415 & & & $*_{-0.505}$ \\
\hline Tianjin & & $* *-0.644$ & & -0.421 & & $* * *-0.717$ & & -0.268 \\
\hline Hebei & $* *-0.642$ & $* * *-0.747$ & $* * *-0.690$ & $* * *-0.760$ & $* *-0.630$ & $* * *-0.768$ & $* *-0.682$ & $* * *-0.770$ \\
\hline Shanxi & -0.016 & -0.113 & -0.124 & 0.024 & -0.154 & -0.082 & 0.072 & 0.020 \\
\hline Neimenggu & & & -0.335 & $*_{-} 0.526$ & & & -0.082 & $* *-0.575$ \\
\hline Liaoning & & $* * *-0.713$ & -0.337 & $* *-0.591$ & & -0.368 & $*_{-} 0.516$ & -0.384 \\
\hline Jilin & -0.248 & -0.295 & & & -0.288 & $*_{-} 0.507$ & & \\
\hline Heilongjiang & -0.027 & -0.079 & -0.450 & -0.375 & -0.143 & -0.022 & -0.290 & -0.261 \\
\hline Shanghai & -0.170 & -0.248 & -0.085 & 0.022 & -0.099 & -0.193 & -0.040 & 0.039 \\
\hline Jiangsu & -0.259 & -0.303 & & -0.149 & -0.265 & -0.336 & & -0.148 \\
\hline Zhejiang & -0.165 & -0.263 & -0.251 & -0.167 & -0.148 & -0.242 & -0.230 & -0.152 \\
\hline Anhui & -0.112 & -0.277 & -0.315 & -0.444 & -0.066 & -0.021 & 0.079 & 0.192 \\
\hline Fujian & -0.285 & $*_{-}-0.492$ & -0.317 & -0.228 & -0.221 & -0.429 & -0.310 & -0.252 \\
\hline Jiangxi & & -0.464 & $* *-0.636$ & -0.313 & & 0.161 & 0.248 & 0.219 \\
\hline Shandong & $* * *-0.697$ & $* * *-0.694$ & $* * *-0.697$ & $* * *-0.694$ & $* * *-0.701$ & $* *-0.689$ & $* * *-0.702$ & $* * *-0.701$ \\
\hline Henan & $*_{-}-0.475$ & $*_{-}-0.476$ & & -0.254 & 0.150 & 0.080 & & 0.086 \\
\hline Hubei & -0.331 & -0.291 & -0.200 & -0.242 & 0.026 & 0.042 & 0.080 & 0.179 \\
\hline Hunan & & 0.045 & -0.102 & -0.097 & & -0.235 & -0.123 & -0.119 \\
\hline Guan & -0.218 & -0.243 & -0.168 & -0.017 & -0.124 & -0.176 & -0.175 & -0.044 \\
\hline Guan & -0.326 & -0.380 & -0.245 & -0.412 & -0.373 & -0.408 & -0.159 & -0.342 \\
\hline Haina & 0.001 & & & & 0.139 & & & \\
\hline Chongq & & -0.300 & -0.400 & -0.231 & & -0.353 & -0.415 & -0.335 \\
\hline Sichue & -0.439 & $* *-0.572$ & $*_{-0.544}$ & $* *-0.624$ & -0.375 & $*_{-} 0.475$ & $* *-0.521$ & $* *-0.647$ \\
\hline Guizhou & & -0.003 & -0.177 & -0.070 & & -0.143 & -0.267 & -0.236 \\
\hline Yunnan & & -0.218 & -0.431 & -0.195 & & -0.379 & $* *-0.635$ & -0.441 \\
\hline Tibet & & & & & & & & \\
\hline Shaanxi & -0.084 & -0.025 & -0.157 & -0.139 & -0.105 & -0.094 & -0.303 & -0.309 \\
\hline Gans & & & & & & & & \\
\hline Qinghai & & $*_{-} 0.508$ & -0.041 & -0.401 & & $* *-0.559$ & -0.031 & -0.333 \\
\hline & & & & & & & & \\
\hline Xinji & -0.151 & -0.161 & 0.334 & -0.445 & 0.035 & 0.061 & 0.093 & -0.124 \\
\hline Nor & -0.2 & $* *-0.569$ & -0.402 & $* *-0.604$ & -0.179 & -0.360 & $*_{-}-0.488$ & -0.308 \\
\hline Beiji & $*_{-0.481}$ & $* *-0.644$ & & -0.221 & -0.415 & $* * *-0.717$ & & -0.224 \\
\hline North & $* * *-0.727$ & $* * *-0.718$ & $* *-0.687$ & $* * *-0.707$ & $*-0.729$ & $* * *-0.720$ & $* * *-0.690$ & $* * *-0.714$ \\
\hline East & -0.240 & -0.304 & -0.031 & -0.174 & -0.241 & -0.320 & 0.007 & -0.164 \\
\hline South & & & -0.159 & & & 65 & -0.168 & -0.062 \\
\hline & & & -0.135 & & 0.059 & 0.023 & -0.048 & -0.052 \\
\hline & & & -0.030 & & -0.170 & -0.209 & -0.246 & $*_{-} 0.556$ \\
\hline Southwest & -0.451 & -0.405 & -0.410 & -0.414 & -0.409 & $*_{-}-0.528$ & $*_{-}-0.533$ & $* *-0.595$ \\
\hline
\end{tabular}

The 13 sectors covered are the 13 industrial sectors (sectors 2 through 14) out of the total of 17 sectors.

A province's linkage coefficients across the 13 industrial sectors are those of the region in which the province is located.

State share denotes the state's share in the output of all directly reporting industrial enterprises.

Output is value added except in the case of Shanghai, Jiangxi, and Qinghai, where only gross output value added data are available for all years (for Jiangxi in 2000 and Qinghai in 2000 and 2003, value added data would be available but gross output value data are used for consistency). Hubei 2003 also uses gross output value data, because the sum sectoral SOSCE value added data significantly exceed the total for Hubei's SOSCEs (only for 2000 would gross output value data also have been available; in years other than 2003, value added is used). For each province, output 
data on the 40 individual sectors are aggregated to match the 13 industrial sector aggregation in the 1997 regional input-output table.

An empty cell means that no data are available on the output either of the directly reporting industrial enterprises, or of the state-owned enterprises, or of both.

The "state" means SOEs in 1994 and 1997, and typically SOSCEs in the other years (with a very few exceptions, where the provincial statistics come according to the old SOE definition).

Significance levels: * $10 \%, * * 5 \%, * * * 1 \%$.

For the regional coverage see note 38 . Because linkage coefficients are regional values, combining these with (aggregated) regional state shares, done in the bottom part of the table, yields the most meaningful correlation coefficients.

Sources: total linkage indicators calculated from SIC (2005) (or see Table 3 and Table 4); output data from provincial statistical yearbooks of the relevant years, supplemented with sectoral output data on the directly reporting industrial enterprises from the Industrial Yearbook in 1994 for Hebei, Shanghai, and Xinjiang, and in 1997 for Shanghai and Qinghai. 
Table 6. Explaining Provincial Growth

\begin{tabular}{|c|c|c|c|c|c|c|c|c|c|}
\hline & $\mathrm{I}$ & II & III & IV & V & VI & VII & VIII & IX \\
\hline \multirow[t]{2}{*}{ Constant } & $* * * * 11.05$ & $* * * * 12.58$ & $* * * * 10.44$ & $* * * * 4.76$ & $* * * * 6.96$ & $* * * * 5.69$ & $* * * * 7.59$ & $* * * * 4.62$ & $* * * * 7.02$ \\
\hline & (1.99) & $(1.91)$ & $(1.41)$ & $(0.83)$ & $(1.40)$ & $(0.80)$ & $(1.54)$ & $(0.88)$ & $(1.46)$ \\
\hline \multirow[t]{2}{*}{ Dummy 1994-97 } & $* * * * 2.53$ & $* * * 5.19$ & $* * * 4.98$ & $* * * * 3.00$ & $* * * * 7.04$ & $* * * * 3.11$ & $* * * * 6.75$ & $* * * * 3.30$ & $* * * * 7.49$ \\
\hline & $(0.43)$ & $(1.55)$ & $(1.62)$ & $(0.50)$ & $(1.43)$ & $(0.58)$ & $(1.58)$ & $(0.59)$ & $(1.48)$ \\
\hline \multirow[t]{2}{*}{ Dummy 2000-03 } & $* * * * 1.50$ & -1.18 & -0.76 & $* * * * 1.61$ & -0.88 & $* * * 1.51$ & -1.43 & $* * * 1.66$ & -0.48 \\
\hline & $(0.41)$ & $(1.40)$ & $(1.47)$ & $(0.47)$ & $(1.28)$ & $(0.54)$ & $(1.43)$ & $(0.54)$ & $(1.36)$ \\
\hline \multicolumn{10}{|l|}{ Industrial sector variables } \\
\hline \multirow[t]{2}{*}{ TOL } & -3.10 & $* *-4.42$ & & & & & & & \\
\hline & $(2.33)$ & $(2.03)$ & & & & & & & \\
\hline \multirow{2}{*}{$\mathrm{CV}$ of TOL } & -1.55 & -0.72 & & & & & & & \\
\hline & $(4.37)$ & $(3.81)$ & & & & & & & \\
\hline \multirow[t]{2}{*}{ TPL * dummy 1994-97 } & & & & $* * * * 112.7$ & $* * 64.36$ & & & 90.13 & 272.16 \\
\hline & & & & $(26.0)$ & $(28.25)$ & & & $(185.71)$ & $(170.78)$ \\
\hline \multirow[t]{2}{*}{ TPL * dummy 1997-00 } & & & & $* * * * 146.7$ & $* * * * 118.95$ & & & $* 252.04$ & 187.44 \\
\hline & & & & $(25.7)$ & $(27.10)$ & & & $(150.04)$ & $(136.15)$ \\
\hline \multirow[t]{2}{*}{ TPL * dummy 2000-03 } & & & & $* * * * 147.0$ & $* * * * 126.64$ & & & $* * * 190.82$ & $* * * 168.09$ \\
\hline & & & & $(25.6)$ & $(28.91)$ & & & $(64.54)$ & $(58.26)$ \\
\hline \multirow[t]{2}{*}{ CV of TPL } & & & & -10.74 & 29.95 & & & -16.84 & 20.28 \\
\hline & & & & $(26.33)$ & $(24.43)$ & & & $(30.59)$ & $(28.47)$ \\
\hline \multirow[t]{2}{*}{ SOE share * dummy $1994-97$} & & $* * * *-7.47$ & $* * * *-7.26$ & & $* * * *-8.02$ & & $* * * *-7.36$ & & $* * * *-8.82$ \\
\hline & & $(1.94)$ & $(1.98)$ & & $(1.74)$ & & $(1.85)$ & & $(1.87)$ \\
\hline \multirow[t]{2}{*}{ SOE share * dummy $1997-00$} & & $* *-3.52$ & $* *-3.65$ & & $*-2.52$ & & -2.33 & & $*-2.52$ \\
\hline & & $(1.62)$ & $(1.68)$ & & $(1.43)$ & & $(1.54)$ & & $(1.46)$ \\
\hline \multirow[t]{2}{*}{ SOE share * dummy $2000-03$} & & 0.67 & 0.10 & & 1.07 & & 2.04 & & 0.59 \\
\hline & & $(1.57)$ & $(1.62)$ & & $(1.31)$ & & $(1.54)$ & & $(1.51)$ \\
\hline \multirow[t]{2}{*}{ CV of SOE share } & & $* 6.80$ & 4.85 & & -1.47 & & 1.34 & & -2.62 \\
\hline & & $(3.76)$ & $(3.72)$ & & $(3.22)$ & & $(3.42)$ & & $(3.40)$ \\
\hline \multirow[t]{2}{*}{ TPL-SOE * dummy 1994-97 } & & & & & & $* * * 81.71$ & 42.52 & 21.51 & -207.49 \\
\hline & & & & & & $(27.20)$ & $(28.49)$ & $(181.13)$ & $(164.92)$ \\
\hline \multirow[t]{2}{*}{ TPL-SOE * dummy 1997-00 } & & & & & & $* * * * 121.36$ & $* * * * 97.08$ & -105.27 & -64.20 \\
\hline & & & & & & $(27.04)$ & $(27.62)$ & $(147.78)$ & $(129.00)$ \\
\hline \multirow[t]{2}{*}{ TPL-SOE * dummy 2000-03 } & & & & & & $* * * * 118.22$ & $* * * 100.67$ & -37.60 & -36.03 \\
\hline & & & & & & $(26.90)$ & $(29.71)$ & $(63.38)$ & $(62.35)$ \\
\hline \multirow[t]{2}{*}{ Central region dummy } & & & & $* * * * 5.54$ & $* * * * 4.54$ & $* * * * 4.43$ & $* * * 3.38$ & $* * * * 5.86$ & $* * * * 4.79$ \\
\hline & & & & $(1.06)$ & $(1.13)$ & $(1.08)$ & $(1.13)$ & $(1.17)$ & $(1.27)$ \\
\hline square & 0.39 & 0.63 & 0.57 & 0.63 & 0.76 & 0.56 & 0.70 & 0.64 & 0.77 \\
\hline
\end{tabular}


except in the case of Guizhou).
enit of analysis is the province

Significance levels: * $10 \%, * * 5 \%, * * * 1 \%, * * * * 0.1 \%$.

Residuals are normally distributed and homoscedastic (at the 5\% significance level using the Jarque-Bera statistic and White's heteroscedasticity test), except in the second regression, where heteroscedasticity is indicated and was not corrected (robust standard errors in the second regression would be smaller for all coefficients). Ramsey RESET tests with three fitted values ( $2^{\text {nd }}$ to $4^{\text {th }}$ power $)$ do not suggest misspecification of any of the regressions.

TOL: average sectoral total output linkage coefficient: region-specific sectoral linkage values weighted by provincial first-year sectoral value added of the directly reporting industrial enterprises.

$\mathrm{CV}$ : coefficient of variation (with provincial first-year sectoral value added of the corresponding enterprise group as weight).

TPL: average sectoral total profit linkage coefficient: region-specific sectoral linkage values weighted by provincial first-year sectoral value added of the directly reporting industrial enterprises.

SOE share: SOE share in value added of the directly reporting industrial enterprises; province-specific average across sectors, with provincial first-year sectoral value added of the directly reporting industrial enterprises as weights.

TPL-SOE: SOE average sectoral total profit linkage coefficient: region-specific sectoral linkage values weighted by provincial first-year sectoral SOE value added (SOE value added in this sector divided by provincial SOE value added).

Central region: Shanxi, Henan, Anhui, Hubei, Hunan, Jiangxi. (A dummy variable is needed in regressions that involve TPL due to the negative TPL values of most sectors in the central region.)

Number of observations: maximally 31 provinces in each of the three periods, except for the non-existence of Chongqing in 1994 ( 92 observations total). Hainan Province is omitted in the first period (see note 52). The regressions have fewer observations because sectoral value added data are not available for all provinces at all times; observations are available for the years 1994, 1997, and 2000 for the same provinces for which correlation coefficients are reported in Table 5, except for a few provinces as reported in the notes to that table where value added data is not available (needed here for consistency) and gross output value was used in Table 5.

Sources: Provincial real GDP growth: individual provincial statistical yearbooks of 2006 (incorporating the economic census revisions of 2004 except in the case of Guizhou); missing values are obtained from Fifty-five Years. Total linkage coefficient: Table 3 and Table 4 (for output and profit linkage). Province-specific sector-specific SOE share and sectoral share in provincial industrial value added: individual provincial statistical yearbooks. 
Appendix 1. Sectoral Classification

\begin{tabular}{|c|c|c|}
\hline 1997 input-output table & 1993-2001 & 2002- \\
\hline \multicolumn{3}{|l|}{ 农业 } \\
\hline \multirow[t]{7}{*}{ 采选业 } & 煤炭采选业 & 煤炭采和洗选业 \\
\hline & 石油和天然气采业 & 石油和天然气开采业 \\
\hline & 黑色金属矿采选业 & 黑色金属矿采选业 \\
\hline & 有色金属矿采选业 & 有色金属矿采选业 \\
\hline & 非金属矿采选业 & 非金属矿采选业 \\
\hline & 木材及竹材采运业 & \\
\hline & 其它矿采选业 & 其它采矿业 \\
\hline \multirow[t]{4}{*}{ 食品制造及烟草加工业 } & 食品加工业 & 农副食品加工业 \\
\hline & 食品制造业 & 食品制造业 \\
\hline & 饮料制造业 & 饮料制造业 \\
\hline & 烟草加工业 & 烟草制品业 \\
\hline \multirow[t]{3}{*}{ 纺织服装业 } & 纺织业 & 纺织业 \\
\hline & 服装及其它纤维制品制造 & 纺织服装, 鞋, 帽制造业 \\
\hline & 皮革毛皮羽线及其制品业 & $\begin{array}{l}\text { 皮革, 毛皮, 羽毛, (线) 及其制 } \\
\text { 品业 }\end{array}$ \\
\hline \multirow[t]{2}{*}{ 木材加工及家具制造业 } & 木材加工及竹藤棕草制品业 & $\begin{array}{l}\text { 木材加工及木, 竹, 疼, 棕, 草制 } \\
\text { 品业 }\end{array}$ \\
\hline & 家具制造业 & 家具制造业 \\
\hline \multirow[t]{3}{*}{ 造纸印刷及文教用品制造业 } & 造纸及纸制品业 & 造纸及纸制品业 \\
\hline & 印刷业,记录媒介的复制 & 印刷业和记录媒介的复制 \\
\hline & 文教体育用品制造业 & 文教体育用品制造业 \\
\hline \multirow[t]{6}{*}{ 化学工业 } & 石油加工及炼焦业 & 石油加工, 炼焦及核燃料加工业 \\
\hline & 化学原料及化学制品制造业 & 化学原料及化学制品制造业 \\
\hline & 医药制造业 & 医药制造业 \\
\hline & 化学纤维制造业 & 化学纤维制造业 \\
\hline & 橡胶制品业 & 橡胶制品业 \\
\hline & 塑料制品业 & 塑料制品业 \\
\hline 非金属矿物制品业 & 非金属矿物制品业 & 非金属矿物制品业 \\
\hline \multirow{2}{*}{ 金属冶炼及制品业 } & 黑色金属冶炼及压延加工业 & 黑色金属冶炼及压延加工业 \\
\hline & $\begin{array}{l}\text { 有色金属冶炼及压延加工业 } \\
\text { 金属制品业 }\end{array}$ & $\begin{array}{l}\text { 有色金属冶炼及压延加工业 } \\
\text { 金属制品业 }\end{array}$ \\
\hline \multirow[t]{2}{*}{ 机械工业 } & 普通机械制造业 & 通用设备制造业 \\
\hline & 专用设备制造业 & 专用设备制造业 \\
\hline \multirow{3}{*}{$\begin{array}{l}\text { 交通运输设备制造业 } \\
\text { 电气机械及电子通信设备制造业 }\end{array}$} & 交通运输设备制造业 & 交通运输设备制造业 \\
\hline & 电气机械及器材制造业 & 电气机械及器材制造业 \\
\hline & 电子及通信设备制造业 & $\begin{array}{l}\text { 通信设备, 计算机及其它电子设备 } \\
\text { 制造业 }\end{array}$ \\
\hline \multirow[t]{2}{*}{ 其它制造业 } & 仪器仪表及文化,办公用机械 & 仪器仪表及文化,办公用机械制造业 \\
\hline & $\begin{array}{l}\text { 其它制造业 } \\
\text { 武器弹药制造业 }\end{array}$ & 工艺品及其它制造业 \\
\hline \multirow{4}{*}{$\begin{array}{l}\text { 电力蒸气热水, 煤气自来水生产 } \\
\text { 供应业 }\end{array}$} & & 废弃资源和废旧材料回收加工业 \\
\hline & 电力蒸汽热水生产供应业 & 电力, 热力的生产和供应 \\
\hline & 煤气的生产和供应业 & 煤气生产和供应业 \\
\hline & 自来水的生产和供应业 & 水的生产和供应业 \\
\hline \multicolumn{3}{|l|}{ 建筑业 } \\
\hline \multicolumn{3}{|l|}{ 商业, 运输业 } \\
\hline 其它服务业 & & \\
\hline
\end{tabular}

Sources: SIC (2005), Statistical Yearbook of mid- or late 1990s and of 2006. The weapons and ammunition sector is not listed in the Statistical Yearbook, but occasionally appears in provincial statistical yearbooks. 